\title{
Dergiabant
}

Cilt/Volume: 9, Sayı/Issue: 1

(Mayıs/May 2021)

\section{Hz. Âdem'in Yaratılışı, İnsanlığın Çoğalması ve Diğer Yaratılış Meselelerinin Kur'ân Açısından Değerlendirilmesi}

\section{An Assessment in the Context of the Qur'ān; the Creation of Adam, the Proliferation of Humanity and Other Creation Issues}

\author{
Cahit Karaalp \\ Dr. Öğr. Üyesi, Muş Alparslan Üniversitesi, İslami İlimler Fakültesi, \\ Tefsir Anabilim Dalı \\ Asst. Prof. Dr., Mus Alparslan University, Faculty of Islamic Sciences, \\ Department of Tafsir \\ Mus/Turkey \\ cahitkaraalp@hotmail.com \\ orcid.org/0000-0001-5898-6819
}

\section{Makale Bilgisi Article Information}

Makale Türü: Araştırma Makalesi

Geliş Tarihi: 5 Mart 2021

Kabul Tarihi: 19 Nisan 2021

Yayın Tarihi: 30 Mayıs 2021

Yayın Sezonu: Bahar
Article Type: Research Article

Date Received: 5 March 2021

Date Accepted: 19 April 2021

Date Published: 30 May 2021

Publication Season: Spring

https://doi.org/10.33931/abuifd.891864

İntihal/Plagiarism

Bu makale özel bir yazılımla taranmıș ve intihal tespit edilmemiștir. This article has been scanned by a special software and no plagiarism detected.

\section{Atıf/Cite as}

Karaalp, Cahit. “Hz. Âdem'in Yaratılışı, İnsanlığın Çoğalması ve Diğer Yaratılış Meselelerinin Kur'ân Açısından Değerlendirilmesi”. Dergiabant 9/1 (Mayıs 2021), 27-63. https://doi.org/10.33931/abuifd.891864

Copyright $\odot$ Published by Bolu Abant Izzet Baysal University Faculty of Theology, Bolu, 14030 Turkey. All rights reserved. https://dergipark.org.tr/tr/pub/dergiabant 


\title{
Hz. Âdem'in Yaratılışı, İnsanlığın Çoğalması ve Diğer Yaratılış Meselelerinin Kur'ân Açısından Değerlendirilmesi*
}

\section{Öz}

Yaratılış konusu, tüm dinlerin ve felsefi akımların tartışma konusu olmuştur. İlk inen vahiy insanın yaratılışını konu edinerek başlamıştır. Illk insanın evrimleșerek mi insan haline geldiği yoksa insan olarak mı yaratıldığı tartışma konusu olmuştur. Evrimi kabul eden İslâm âlimleri bulunmakta ise de çoğunluk evrimi reddetmiştir. Hz. Âdem'in yaratılışı da tarih boyunca tartışma konusu olmuştur. Hâkim görüş Hz. Âdem'in insanlığın babası ve ilk insan olduğu yönünde olsa da Hz. Âdem'in ilk insan olmadığı̆, ondan önce birçok Âdem'in bulunduğu yönünde görüşler bulunmaktadır. İnsanlığın kardeş evliliği yoluyla mı yoksa birçok Âdem'in yaratılması suretiyle mi çoğaldığı da tartışma mevzusudur. Çalışmamızda yaratılış konusundaki tartışmalı konulara değinilecek ve Kur'ân merkezli cevaplar verilecektir. İnsanlığın çoğalması, Hâbil-Kabil meselesi, kalu bela olayı, meleklerin secdesi, Âdem'in yaratılışı, Âdem'e yasaklanan meyve, Âdem'in cenneti, Âdem'e üflenen ruh gibi yaratılışla ilgili müșkil meseleler Kur'ân bağlamında tartışılacak ve meseleler çözümlenmeye çalışlacaktır. Makalemizde Hz. Âdem'in kıssası bağlamında tefsirlerde aktarılan israiliyât kökenli bilgiler ayıklanarak ilk insan ile ilgili birçok sorunun cevabı Kur'ân'da aranacaktır.

Anahtar Kavramlar: Kur'ân, Kıssa, Yaratılış, Evrim, Hz. Âdem.

\section{An Assessment in the Context of the Qur'ān; the Creation of Adam, the Proliferation of Humanity and Other Creation Issues}

\begin{abstract}
The subject of creation has been a matter of debate for all religions as well as philosophical currents. The first revelation was about explaining the creation of man. It has been a matter of debate whether initially humans are a result of the evolutional process or they were just created. Although few Islamic scholars accept evolution, the majority rejected it. Prophet Adam's creation has also been the subject of discussion throughout history. Despite a few Islamic scholars who support the idea of evolution and the existence of many humans before the prophet Adam, the common idea is that the prophet Adam was the first human as the father of all human beings. It is also a matter of debate whether humanity reproduced through brotherly marriage or the creation of many Adams. In the current research, the controversial issues regarding creation will be addressed and the Qur'ān-centered answers will be given. Problems related to creation such as the reproduction of humanity, the issue of Abel-Cain, the incident of the testimonial to the God (Qālū Balā), the prostration of angels, the creation of Adam, the forbidden fruit, Adam's paradise, and the spirit blown to Adam will be discussed in the context of the Qur'ān and the issues will be tried to be resolved. In the current study, the answers to many questions about the first human will be sought in the Qur'ān by eliminating the Israelite information conveyed in the commentaries in the context of the parable of Adam.
\end{abstract}

Keywords: Qur’ān, Parable, Creation, Evolution, Adam.

Makalemiz, 8-9 Kasım 2018 tarihinde Erzurum'da düzenlenen II. Uluslararası Bilimler Işı̆̆ında Yaratılıș Kongresi'nde sözlü olarak sunduğumuz "Kur'an'a Göre Hz. Âdem'in Yaratılıșı" adlı tebliğimizin yeniden ele alınması ve başlık dâhil içeriğinin tamamen değiștirilmesi suretiyle elde edilmiştir. 


\section{Giriş}

İslâm dininin insana öğretmek istediği ilk şey, Allah'ın yaratıcı olduğu ve kâinatın Allah tarafından yaratıldığı gerçeğidir. Nitekim Allah'ın peygamber vasıtasıyla insanlığa gönderdiği ilk âyetlerde ${ }^{1}$ öncelikle bu gerçek bildirilmiştir. ${ }^{2}$ Tarih boyunca tüm dinlerin ve düşünürlerin ilgi konusu olan yaratılış meselesi Kur'ân'ın ve diğer kutsal kitapların üzerinde durduğu önemli konulardan biridir. Eski Ahid yaratılış konusu ile başlamaktadır. ${ }^{3}$ İncillerde yaratılış konusunda ise bilgi bulunmamaktadır. ${ }^{4}$ Kur'ân'ın ilk nazil olan sûresinde, "Halk eden/yaratan Rabbinin ismiyle oku. O, insanı alaktan/kan pıhtısından halk etti/yarattı" âyeti ile başlangıç olarak insanın yaratılışına dikkat çekilir. Bu da, yaratılış mevzusunun insan için ne kadar önemli olduğunu göstermektedir. ${ }^{5}$ Kur'ân, bir astronomi kitabı olmadığından yaratılış ile ilgili detaylı bilgiler vermemektedir. ${ }^{6}$

Kur'ân, üslubunun gereği olarak yaratılışla ilgili bilgileri detaylı ve teknik olarak değil hem kısa ve veciz bir halde, hem de çeşitli sûre ve âyetlerde dağınık biçimde vermektedir.7 Tefsirler ise Kur'ân'ın yaratılış ile ilgili zikrettiği mevzuları israiliyyat türü haberlerden naklettikleri bilgilerle ikmal etmiş ve detaylandırmışlardır. ${ }^{8}$

Kur'ân'da yaratmayı ifade eden "Halk, Fatr, Ber', Bed', Ca'l, Sun', Kevn, Tasvir, Tesviye" gibi birçok kavram var" ise de en öne çıkanı "خلق/halk" kavramıdır. Çokanlamlı bir kelime olan halk kavramı Arap dili sözlüklerinde, "takdir etmek" ve "yaratmak" anlamlarına gelmektedir.10 Zemahşerî (öl. 538/1144), "halk" kelimesinin "takdire bağlı olarak var etme" anlamına geldiğini ifade eder.11 Mukâtil bin Süleymân (öl. 150/767) "halk” kavramının Kur'ân'da; “din, iftira atmak-uydurmak, tasvir etmek, nutk/konuşturmak, ceale/kllmak, diriltmek/ba's, yaratmak" gibi anlamlarda

el-Alak 96/1-2.

Mehmet Bayrakdar, İslam'da Evrimci Yaratılış Teorisi (Ankara: Otto Yay., 2018), 29.

Evin Bilge, "Kutsal Metinlerde Yaratılış", Dicle Üniv., Illahiyat Fak. Dergisi 15/1 (2013), 128-158.

Nurullah Agitoğlu, Peygamberimizin (SAS) Dilinden Hz. Âdem (İstanbul: Kitabi Yay., 2015), 32.

İsmail Cerrahoğlu, "Kur'an'da İnsanın Yaratılış Sahnesinin Düșündürdükleri", Ankara Üniv. Ilahiyat Fak. Dergisi 20 (1975), 87.

$6 \quad$ Hatice Kelpetin Arpaguş, Osmanlı Halkının Geleneksel İslam Anlayışı ve Kaynakları (İstanbul: Çamlıca Yay., 2001), 135-142.

7 Bayrakdar, İslam'da Evrimci Yaratılıș Teorisi, 30; Mustafa Öztürk, Kur'an ve Yaratılış (İstanbul: Kuramer Yay., 2015), 192.

8 Ulvi Murat Kılavuz, “Arâisü'l-Kur'an'da Yaratılıș Kıssası”, Ulusal Vânî Mehmed Efendi Sempozyumu 7-8 Kasım 2009 (Bursa, 2011), 171.

9 Öztürk, Kur'an ve Yaratılış, 18-38.

10 Ebû Abdurrahmân Halîl b. Ahmed el-Ferâhîdî, Kitâbu'l-ayn, thk. Dr. Davud Sellum v.dğr. (Beyrut: Mektebetü Lübnân, 2004), 222; Ebû Bekr Muhammmed b. Hasan b. Dureyd el-Ezdî, Cemheratu'lluğâ, thk. İbrahîm Şemsuddîn (Beyrut: Dâru'l-Kütübi'l-İlmiyye, 2005), 1/734; Ebû Mansûr Muhammed b. Ahmed el-Ezherî, Mu'cemu tehzîbi'l-luğâ, thk. Riyâz Zekî Kâsım (Beyrut: Dâru'lma'rife, 2001), 1/1093; Ebu'l Huseyn Ahmed bin Fâris bin Zekeriyyâ, Mekâyîsu'l-luğâ, thk. Enes Muhammed eș-Șâmî (Kâhire: Dâru'l-Hadîs, 2008), 268; İsmâîl bin Hammâd el-Cevherî, Mu'cem es-sıhâh, thk. Halîl Me'mun Şeyhâ (Beyrût: Dâru'l-Ma'rife, 2008), 314; Ebû Hasen Alî bin İsmâîl bin Sîde el-Mursî, el-Muhkem ve'l-muhit el-a'zam, thk. Abdulfettâh es-Seyyid Selim- Huseyn Birkân (Kahire: Ma'hed Mahtutati'l-Arabiyye, 2011), 1/389.

11 Ebû'l-Kâsım Cârullah Mahmûd bin Ömer bin Muhammed ez-Zemahșerî, Esâsu'l-belâğa (Dimeşk: Dâru'n-Nefâis, 2009), 160. 
kullanıldığını söylemiștir.12 Yaratma/halk kelimesi, Kur'ân'da bir şeyin yaratılmadan önce takdir edilmesi, yaratılan bir şeyden yeni bir şeyin var edilmesi ve bir şeyin şekil ve şemâlinin değiştirilerek değiştirerek yeni bir şeyin ortaya çıkarılması anlamında kullanılmıştır. ${ }^{13}$ Makalemizde Hz. Âdem'in yaratılışı, yaratılış kıssasının gerçekliği, ilk insanın kimliği, insanlığın çoğalması ve yaratılışla ilgili diğer konular Kur'an bağlamında değerlendirilecek ve son dönemde insanın yaratılışı ile ilgili tartışmalar üzerinde durulacaktır.

\section{Yaratılıș Kıssasının Temsili/Sembolik Olması}

Batıda Kitab-ı Mukaddes'in mitolojik unsurlardan arındırılması çabası sonrasında İslâm dünyasında kıssaların gerçekliği sorgusu başlamış, Kur'ân'da makul olmayan bir şeyin bulunmadığı, makul görünmeyen şeylerin mecazi veya sembolik olabileceği ifade edilmiş, Hz. Âdem kıssasının sıra dışı ve olağanüstü bir anlatı olması nedeniyle kıssanın temsili bir yapı arz ettiği, gerçekliğinin bulunmadığı belirtilmişș ve kıssanın insanın ilim, çoğalma ve kudret arzusunu gösterdiği ifade edilerek kıssadan çeşitli açılardan mesajlar çıkarılmıştır.15

Kıssaların temsili oldukları, gerçeklik ifade etmedikleri meselesi Muhammed Ahmed Halefullah'ın el-Fennü'l- Kasasi fi'l-Kur'ân ${ }^{16}$ adlı eseriyle İslâm aleminin gündemine gelmiş ve bazı ilahiyatçılar tarafından kabul görmüştür. ${ }^{17}$ Âdem kıssası bazı araştırmacılar tarafından temsili-menkıbevi bir kıssa olarak kabul edilmiştir. ${ }^{18}$ Âdem kıssasının, Âdem ile İblis, hayır ile șer veya iyi duygular ile kötü duygular arasındaki mücadelenin kıssası olduğu iddia edilmiștir. ${ }^{19}$ Hz. Âdem, Hz. Havvâ, iblis/şeytan, cennet, cennetten çıkarılma, yasak ağaç, çıplaklık ve günahtan tövbe gibi ifadelerin hepsi kişiye, kendisi ve dünya ile ilgili geniş ufuklu anlamlandırmalar yapabilmesini sağlayacak sembolik unsurlar olarak değerlendirilmişlerdir. ${ }^{20}$ Sadece Âdem'in değil tüm insanlığın topraktan yaratıldığı, kıssada zincirin bir halkasına

12 Mukâtil bin Süleymân bin Beşîr, el-Eşbâh ve'n-nezâir fi'l-Kur'âni'l-Kerîm, thk. Abdullâh Şehhâte (Kâhire: Dâru Ğarib, 2001), 255-257. Ayrıca bk. Ebu Hilâl el-Askerî, Hasen bin Abdullâh, el-Vücûh ve'n-nezâir fi'l-Kur'âni'l-Kerîm, thk. Ahmed es-Seyyid (Beyrut: Dâru'l-Kütübi'l-İlmiyye, 2010), 148; Ebû'l-Ferâc Cemalüddîn Abdurrahmân bin Alî bin Muhammed el-Cevzî, Nüzhetü'l-a'yüni'nnevâzır fi ilmi'l-vücûh ve'n-nezâir, thk. Muhammed Osmân (Kâhire: Mektebetu's-Sekâfeti'dDiniyye, 2014), 169.

13 Şakir Kocabaş, Kur'an'da Yaratılış Uzayların ve Maddenin Yaratılışıı (İstanbul: Kure Yay., 2017), 60.

14 Şehmus Demir, Mitoloji,Kur'an Kıssaları ve Tarihi Gerçeklik (İstanbul: Beyan Yay., 2015), 146-147.

15 Muhammed İkbal, İslamda Dini Tefekkürün Yeniden Teşekkülü, çev. Sofi Huri (İstanbul: Kırkambar Yay., 1999), 102.

16 Muhammed Ahmed Halefullah, el-Fennü'l-Kasasi-Kur'an'da Anlatım Sanatı, çev. Şaban Karataş (Ankara: Ankara Okulu Yayınları, 2012), 383.

17 İlgili fikirlerin savunusu için bk. Mustafa Öztürk, Kıssaların Dili (Ankara: Ankara Okulu Yay., 2012).

18 Öztürk, Kıssaların Dili, 145; Saadettin Merdin, İslamın Pavlusları II (Ankara: Araştırma Yay., 2016), 212.

Halefullah, el-Fennu'l-Kasasi, 271-274.

20 Hidayet Şefkatli Tuksal, Kadın Karşıtı Söylemin İslâm Geleneğindeki İzdüşümleri (Ankara: Otto Yay., 2012), 106. 
dikkat çekildiği, Âdem ve toprağın sembol olduğu, elementer kökeni ve beslenme kaynağını sembolize ettikleri de ileri sürülmüştür. ${ }^{21}$

İslâm âlimleri kıssaların temsili olduğu fikrini reddetmiş, ${ }^{22}$ kıssalarda temel amacın tarihi olayları ayrıntılarıyla ortaya koymak değil mesaj vermek olduğunu, kıssaların ibret alınacak tarihi doğruluğa ve gerçekliğe sahip olaylar olduklarını ${ }^{23}$ ve gerçekleşmiş olaylar üzerinden muhataba verilen mesajın daha etkili olacağını ifade etmişlerdir. ${ }^{24}$ Bize göre Adem kıssası, "yasak ağaç" gibi mecazi ifadeler ihtiva eden, insanlığın ilk günlerinde yaşananları detaya girmeden mesaj merkezli anlatan, mitolojik ve masalımsı anlatımlardan uzak, hak olarak aktarılan ilahi bir anlatımdır ve temsili değildir. Zira Hz. Meryem'e kimin kefil olacağının işlendiği Âl-i İmrân, 3/44. ayette Hz. Peygambere, "onlar kalemlerini/oklarını atarlarken sen yanlarında değildin" denilerek kıssaların yaşanmış hikâyeler olduğu ima edilmiştir.

\section{2. Âdem'in İsminin Kökeni ve Anlamı}

Kur'ân'da 25 defa geçen ${ }^{25}$ Âdem kelimesinin kökeni ve anlamı konusunda birbirinden farklı bilgiler verilmektedir. Âdem kelimesinin Arapça olduğu, "bir şeyin dış yüzü, cildin alt tarafı veya üst tarafı" anlamına gelen "el-edime/edeme" kökünden türetildiği, "el-edmü" kelimesinin "ülfet ve ittifak" anlamına geldiği, Âdem kelimesinin, "esmerlik, beyazlık, yakınlık, vesile, karışım, hareketlilik" anlamına gelen "el-üdme" kökünden geldiği ifade edilmiştir. ${ }^{26}$ Çoğunluk, Âdem kelimesinin Arapça olduğu, "bir şeyin dış yüzü" anlamına geldiğini ifade etmiştir. ${ }^{27}$ Âdem isminin Arapça olmadığını ifade edenler, kelimenin Arap diline Süryanice, Aramice ve İbranice'den geçtiğini, bunun için de kelimeye Arapça kök aramanın doğru olmadığını belirtmişlerdir.28 Âdem isminin, Sabii lisanındaki "adam/kul”, Asur, Babil lisanındaki

21 Mustafa İslamoğlu, Kur'an ve Tabiat Ayetleri Işığında Yaratılış ve Evrim (İstanbul: Düşün Yay., 2015), 132-133

22 Halefullah'ın ve kıssaların gerçekliğini reddedenlerin görüşlerinin reddi için bk. M. Sait Şimşek, Kur'an Kıssalarına Giriș (Konya: Kitap Dünyası Yay., 2013); Şaban Karataș, Muhammed Ahmed Halefullah Eserleri ve Kur'an Tefsiri ile Illgili Görüssleri (Ankara: Ankara Okulu Yayınları, 2011); Demir, Mitoloji,Kur'an Kıssaları ve Tarihi Gerçeklik.

23 Abdülcelil Bilgin, Kur'an'ı Tanımak (Ankara: Araștırma Yay., 2018), 185-187.

24 Cengiz Duman, Kur'an Kıssalarının Tarihselliği (İstanbul: Ekin Yay., 2015), 165.

25 Muhammed Fuâd Abdulbâkî, el-Mu'cemu'l-müfehres li elfâzı'l-Kur'âni'l-Kerîm (Kâhire: Dâru'lHadîs, 2007), 30-31.

26 Ferâhîdî, Kitâbu'l-ayn, 7; Cevherî, Mu'cem es-sıhâh, 34; Mecdüddîn Muhammed bin Ya'kub elFiruzâbâdî, el-Kâmusu'l-muhît, thk. Halil Me'mun Șeyhâ (Beyrut: Dâru'l-Ma'rife, 2011), 38; Ebu'lKâsım Huseyn bin Muhammed er-Ragıb el-İsfehânî, el-Müfredât fì garîbi'l-Kur'ân, thk. Muhammed Halil Ayteni (Beyrut: Dâru'l-Ma'rife, 2001), 15.

27 Ebû Ca'fer Muhammed bin Cerîr et-Taberî, Câmiu'l-beyân an te'vîli âyi'l-Kur'ân (Beyrut: Dâru İbn Hazm, 2013), 1/281-282; Ebû'l-Hasen Alî bin Muhammed el-Maverdî, en-Nuket ve'l-uyûn, thk. Seyyid Abdulmaksud bin Abdurrahîm (Beyrut: Dâru'l-Kütübi'l-i̇lmiyye, ts.), 1/98-99; Ebû'l-Ferâc Cemalüddîn Abdurrahmân bin Alî bin Muhammed el-Cevzî, Zâdu'l-mesîr fî ilmi't-tefsîr (Beyrut: Dâru İbn Hazm, 2015), 53-54; Fahruddîn Muhammed bin Ömer bin Hasen bin Huseyn bin Alî etTeymî er-Râzî, Mefâtîhu'l-ğayb/Tefsîru'l-kebîr, thk. İbrahîm Şemsuddîn, Ahmed Şemsuddîn (Beyrut: Dâru'l-Kütübi'l-İlmiyye, 2013), 9-10/131; Abdullâh bin Ahmed bin Mahmûd en-Nesefî, Medâriku't-tenzîl ve hakâiku't-te'vîl/Tefsîru'n-Nesefî (Beyrut: Dâru'l-Ma'rife, 2000), 45; Öztürk, Kur'an ve Yaratılış, 151-152. 
adamu/yapılmış, meydana getirilmiş, ortaya konmuş çocuk, genç veya Sümer lisanındaki "adamu/babam" kelimesinden geldiği ${ }^{29}$ veya İbranice'de "ekili alan" anlamına gelen "adamah" kelimesinden türediği ileri sürülmüştür. ${ }^{30}$ Eski doğu dinlerinde "adam" kelimesinin "yerden veya yere ait insanlık" anlamlarına geldiği de belirtilmiştir. ${ }^{31}$

Âdem isminin özel isim mi cins isim mi olduğu tartışma konusudur. Kimi araştırmacılara göre Âdem cins isimdir ve tekil için de kullanılır. Tevrat'ta birçok yerde cins isim olarak kullanılmıştır. ${ }^{32}$ Âdem isminin Aramice olduğunu söyleyenlere göre de ismin cins mi özel mi olduğu konusu tartışmalıdır. Çoğu araştırmacıya göre Âdem kelimesi özel isim iken bazılarına göre ise cins isimdir. Âdem isminin Kur'ân'da özel isimden daha çok insan cinsini gösterdiği,33 bir mefhum olduğu, "sizi yaratıp sonrasında tasvir edip meleklere secde edin dedik" ${ }^{34}$ âyetine istinaden kişiyi değil cinsi ifade ettiği, ${ }^{35}$ İnsanoğlunun tek bir atasının bulunmadığı, Âdem isminin tek bir şahsa değil insan cinsine delalet ettiği iddia edilmiştir. ${ }^{36}$ Kanaatimizce Âdem ismi cins değil özel isimdir. ${ }^{37}$ Zira "Allah, Âdem'i, Nuh'u, İbrahim neslini ve Imran neslini insanlı̆̆ın/âlemlerin üzerine seçkin kıldı" 38 âyetinde Âdem ismi ile birlikte Nuh ismi de kullanılmış ve devamında İbrahim ailesinden, İmrân soyundan bahsedilmiştir. Eğer Âdem kelimesi cins olsaydı, bir soyu ya da insan topluluğunu ifade etmiş olsaydı başına diğerlerinde olduğu gibi “Âl” kelimesi eklenirdi. Ayrıca Hz. İsa'nın durumunun Hz. Âdem'in durumuna benzetildiği âyette ${ }^{39}$ "İsa” isminin cins isim olmaması, tekil ve özel olması "Âdem" isminin de tekil ve özel olmasını gerektirir.

\section{Hz. Âdem'in İlk İnsan ve İlk Peygamber Olması}

Hz. Âdem'in ilk beşer/insan mı yoksa insanlığın/beşerin sembolik atası mı olduğu mevzusu tartışmalıdır. ${ }^{40}$ Genel ve hâkim görüş ilk insanın ve insanlığın atasının Hz. Âdem olduğu ${ }^{41}$ yönündedir. Ancak Hz. Âdem'in ilk defa tek başına

\footnotetext{
29 Süleyman Hayri Bolay, “Âdem”, DIA (Ankara: TDV Yay., 1988), 1/358.

30 Muhammed Tâhir bin Âșûr, Tefsîru't-Tahrîr ve't-Tenvîr (Tûnus: Dâru Suhnûn li'n-Neşr ve't-Tevzi', ts.), 1/408; Mustafa Erdem, Hazreti Âdem (İlk Insan) (Ankara: TDV Yay., 2017), 13; İsmail Yakıt, Kur'ân'ı Anlamak (İstanbul: Ötüken Yay., 2005), 67.

31 Erdem, Hazreti Âdem (Illk Insan), 13.

32 İbrahim Sarmış, Kur'ân'a Göre İnsan'ın Yaratılması ve Çoğalması (İstanbul: Düşün Yay., 2016), 5153.

33 Süleyman Ateș, "Kur'an-ı Kerim'e Göre Evrim Teorisi”, Ankara Üniv. İlahiyat Fakültesi Dergisi 20 (1975), 138-140. el-A'râf 7/11.

İkbal, İslamda Dini Tefekkürün Yeniden Teșekkülü, 101.

Öztürk, Kur'an ve Yaratılış, 153-154; Sarmış, Kur'ân'a Göre İnsan'ın Yaratılması ve Çoğalması, 51. Öztürk, Kur'an ve Yaratılış, 154.

Âl-i İmrân 3/33.

Âl-i İmrân 3/59.

Namık Kemal Okumuș, Eșref'ten Esfel'e Insanın Serüveni (Ankara: Araștırma Yay., 2015), 149.

Ebû Mansûr Muhammed bin Muhammed bin Mahmûd el-Mâturîlî, Tevilâtü Ehli'sSünne/Te'vilâtu'l-Kur'ân, thk. Dr. Mecdi Basillum (Beyrut: Dâru'l-Kütübi'l-İlmiyye, 2005), 3/3; Tâhir bin Âșûr, Tefsîru't-Tahrîr ve't-Tenvîr, 1/408; Cevherî, Mu'cem es-sihâh, 34; Firuzâbâdî, elKâmusu'l- muhît, 38; Ragib el-İsfehânî, el-Müfredât fì garîbi'l-Kur'ân, 15; Öztürk, Kur'an ve Yaratılış, 153.
} 
yaratılmadığı, onunla birlikte erkek-kadın birçok insanın yaratıldığı, Âdem isminin bu insanları ifade eden sembolik bir ifade olduğu, ${ }^{42}$ Âl-i İmrân 3/33. âyette geçen "seçti/istafa" kelimesine dayanarak Hz. Âdem'in yaşam sürdüğü dönemde kendisiyle birlikte var olan bir topluluğun içinden elçi/resul olarak seçildiği fikri de ileri sürülmüştür. ${ }^{43}$ Allah'ın, Hz. Âdem'den önce insan yarattığı ve onların da yeryüzünde bozgunculuk çıkardıkları ifade edilmiştir.44 Ca'fer es-Sadık, İmam Muhammed Bakır ve İbn Arabi'ye göre Hz. Âdem'den önce birçok Âdem yaratılmıştır. ${ }^{45}$

İnsan kelimesinin gerçekte "Homo cinsine mensup bir hayvan" anlamına geldiği, insanların ilk olarak maymun cinsinden evrimleștiği, "zeki insan" 46 adı verilen ilk insan türünün Homo sapiens olduğu ileri sürülmüştür. ${ }^{47} \mathrm{~Hz}$. Âdem'in, insan cinsini sembolize eden bir isim olarak değil de bir kişi olarak düşünüldügünde "Homo sapiens" cinsinin içinde, sorumluluk yüklenecek şekilde kelamı/konuşmayı ilk öğrenen, ilk sorumluluk sahibi, yani "ilk insan” olarak görülebileceği,48 Âdem'in, tekâmül/evrim sonunda akıl ve duyularına kavuşan ilk insanın ismi olduğu da ifade edilmiştir. ${ }^{49}$

İlk insan türünün yaratılışından söz eden âyetlerde insan ${ }^{50}$ ve beşer ${ }^{51}$ kelimeleri kullanılmaktadır.52 Beșer ve insan kelimeleri arasında fark olduğu, beșer kelimesinin cins isim olduğu,53 insanın Allah'ın muhatabı olunca, vahşiliği bitince, davranışlarını kontrol edince beşer olmaktan çıkıp insan haline geldiği iddia edilmiştir. ${ }^{54}$ Buna karşı olarak, Kur'ân'da beşer kelimesi ile insanın fizyolojik yönüne, insan kelimesi ile sosyal yönüne vurgu yapılmış olabileceği55 ve Kehf 18/110 ve Şurâ

42 İslamoğlu, Kur'an ve Tabiat Ayetleri Ișığında Yaratılış ve Evrim, 247.

43 Yakıt, Kur'ân'ı Anlamak, 72; Gürbüz Deniz, “Kur'an'a Göre Hz. Âdem (a.s.)’ın Serüveni”, Journal of Islamic Research 22/2 (2011), 93; Caner Taslaman, Bir Müslüman Evrimci Olabilir mi (İstanbul: Destek Yay., 2017), 96; Hasan Özalp, "Kur'an-ı Kerim'de Kozmik Tarih ve Biyolojik Gelişim”, Turkish Studies, International Periodical For The Languages, Literature and History of Turkish or Turkic 10/1 (2015), 548. İbnu'l-Cevzî, Zâdu'l-mesîr, 52; Abdulfettah Tabbara, Kur'an'da Peygamberler ve Peygamberimiz, çev. Ali Rıza Temel\&Yahya Alkın (İstanbul: Miili Gazete, 1998), 34; Bayraktar Bayraklı, Yeni Bir Anlayışın Işığında Kur'an Tefsîri (İstanbul: Bayraklı Yay., 2013), 1/301. Muhammed Reşîd Rızâ, Tefsîru'l-Kur'âni'l-Hakîm, thk. İbrahim Şemsuddîn (Beyrut: Dâru'lKütübi'l-İlmiyye, 2011), 5/264; Öztürk, Kur'an ve Yaratılış, 153; Erdem, Hazreti Âdem (İlk İnsan), 131. Âdem'den önceki Âdemlerin olduğu konusu ile ilgili bk. İslamoğlu, Kur'an ve Tabiat Ayetleri Işı̆̆ında Yaratılış ve Evrim, 256-259.

46 İslamoğlu, Kur'an ve Tabiat Ayetleri Işı̆̆ında Yaratılıs ve Evrim, 251.

47 Yuval Noah Harari, Hayvanlardan Tanrılara Sapıens Insan Türünün Kısa Bir Tarihi, çev. Ertuğrul Genç (İstanbul: Kolektif Yay., 2015), 19-21. İslamoğlu, Kur'an ve Tabiat Ayetleri Işığında Yaratılış ve Evrim, 258; Nihat Kınıkoğlu, "Varoluş, Evrim, İnsan ve İslam”, İslami Araştırmalar Dergisi 7/1 (1993-94), 76; Taslaman, Bir Müslüman Evrimci Olabilir mi, 96.

49 Ateș, "Kur'an-ı Kerim'e Göre Evrim Teorisi", 140.

50 el-Hicr 15/26; er-Rahmân 55/3, 14; el-İnsân 76/1; el-Alak 96/2.

51 el-Hicr 15/28; Sâd 38/71.

52 Mehmet Okuyan, Kıssalar Ne Söyler Yaratılıș ve Hz. Âdem I (İstanbul: Düșün Yay., 2017), 68.

53 Sarmıș, Kur'ân'a Göre Insan'ın Yaratılması ve Çoğalması, 55

54 Yakıt, Kur'ân'ı Anlamak, 62.

55 Talip Özdeș, Kur'an ve Cinsiyet Ayırımcılı̆ğ (Ankara: Fecr Yay., 2005), 76-77; Sarmıș, Kur'ân'a Göre İnsan'ın Yaratılması ve Çoğalması, 43. 
42/51. âyetlerde beșer kelimesi ile iddia edildiği gibi insanın akıl verilmezden önceki hayvanlık dönemine işaret edilmediği söylenmiștir. ${ }^{56}$

Okuyan; Nisâ 4/1. âyette iki hücreden pek çok erkek ve kadının yaratıldığının söylendiğini, Fâtır 35/11. âyette geçen "ezvac" kelimesinin ilk türün pek çok insan çifti şeklinde yaratıldığını gösterdiğini, Nebe' 78/8. âyette insanların çiftler halinde yaratıldığının buyrulduğunu, A'râf 7/11. âyette "küm/sizi" kalıbında çoğul zamirlerin kullanıldığını ve ardından secde emrinin verildiğini bunun da o dönemde çok insanın varlığına işaret ettiğini, ${ }^{57}$ Âl-i İmrân, 3/33. âyette geçen "seçim" ifadesinin Âdem'in alternatifinin olduğuna ve başka insanların varlığına delalet ettiğini, Hucurât 49/13. âyette ilk insandan değil ilk insan türünden bahsedilmiş olabileceğini, Zümer 39/6. âyette geçen "en'âm" ifadesinin "hayat sahipleri" şeklinde anlaşılması halinde dört çiftten oluşan sekiz grup insanın yaratıldığının anlaşılacağını, Nebe' 78/8; Fâtır, 35/11 ve Nisâ 4/1. âyetlerine istinaden ilk canlı türlerinin "nefsi vâhide"den yaratıldıklarını ${ }^{58}$ ifade etmiş ve Hz. Âdem'in ilk insan olmadığını ispatlamaya çalışmıştır.

Sarmış; şeytan'ın bir isme değil bir topluluğa secde etmeyi reddettiğini, A'râf 7/14-17. âyetlerde geçen şeytan'ın “insanları saptıracağım” sözünün o dönemde birçok beşerin varlığını gösterdiğini, değilse Neml, 27/65. âyette geçen "yerde ve gökte olanlar gaybı bilmez" âyetine istinaden şeytan'n Âdem'in çoğalacağını bilemeyeceğini, Âdem'in "insan" anlamına ${ }^{59}$ geldiğini, Hûd, 11/61. âyette geçen "sizi yeryüzüne yerleştiren" ifadesi ile topraktan yaratılan ilk insan neslinin kastedildiğini, tövbeyi ilk insan neslinin yaptığını, Bakara, 2/36. âyette geçen "oradan inin" ifadesinin çoğul gelmesinin de bunu ifade ettiğini, kan gruplarının birbirinden farklı olmasının da delil olduğunu ${ }^{60}$ söyleyerek ilk insanın Hz. Âdem olmadığı iddiasında bulunmuştur.

Hz. Âdem'in bir toplulukla beraber yaratıldı̆̆ı görüşünü benimseyenler; Kur'ân'da zikredilen "ben-i Âdem/Âdemoğulları" ifadesine "soy bağı" manasının verilmemesi gerektiğini, "ben-i/oğulları" sözcüğünün "onu izleyen, onun izinden giden, onun yolunda olan" anlamına da geldiğini, "ben-i İsrail/İsrailoğulları" tabirinin de âyetlerde geçtiğini ancak Kur'ân'ın muhatap aldığı Yahudilerin hepsinin Hz. Yakub'un neslinden gelmediklerini söylemektedirler. Bu yaklaşıma göre onun adına yapılan atıfların yani Kur'an'ın "Âdemoğulları" tabirini kullanmasının temel sebebi Hz. Âdem'in insanlığın ilk biyolojik babası olması değil, sorumlu ilk insan olması veya ilk insan topluluğunun önderi olmasıdır. ${ }^{61}$

Hz. Âdem'den önce insansı varlıkların veya başka insanların yaratılmış olduğunu ve Hz. Âdem'in de onlara elçilik göreviyle gönderilmiş olabileceğini ileri

\footnotetext{
56 M. Sait Şimşek, Yaratılış Olayı (İstanbul. Beyan Yay., 1998), 52.

57 Okuyan, Kıssalar Ne Söyler Yaratılıș ve Hz. Âdem I, 74-75, 84-85. Ayrıca bk. Sarmıș, Kur'ân'a Göre İnsan'ın Yaratılması ve Çoğalması, 58-60; Taslaman, Bir Müslüman Evrimci Olabilir mi, 95. Okuyan, Kissalar Ne Söyler Yaratıllş ve Hz. Âdem I, 75-80. el-Mü'minûn 23/12-14; es-Secde, 32/7-8.

Sarmıș, Kur'ân'a Göre Insan'ın Yaratılması ve Çoğalması, 59-64.

Yakıt, Kur'ân'ı Anlamak, 70; Taslaman, Bir Müslüman Evrimci Olabilir mi, 93.
} 
sürmek doğru değildir. Bu iddiayı kabul ettiğimizde, meleklerin itirazı yersiz olmaktadır. Mademki Hz. Âdem'den önce bozgunculuk yapan, kan döken, fitne çıkaran insan türü vardı. Allah da doğal olarak bu eylemleri gerçekleştiren bozuk insanları doğru yola getirmek, onları belli bir düzene sokmak, ifsad ve kan akıtmalarının önüne geçmek için bir peygamber tayini etti. Şu hâlde melekler neden böyle düzeltici birini bozgunculuk yapmak ve kan akıtmakla nitelediler?62

Âl-i İmrân, 3/33. âyette geçen "istifa/seçim" kelimesinin "Âdem'in alternatifinin olduğuna ve başka insanların varlı̆̆ına delalet ettiği" iddiasına; "birinin Allah tarafından seçilmesi onunla birlikte başkalarının da maddi olarak var olmasını gerektirmez. Çünkü Allah'ın ilminde bilinen insanlar içerisinden de seçim olabilir. Ayrıca Âdem yaratılıp kendisinden belli bir nesil oluştuktan sonra da Allah Teâlâ Âdem'i seçmiş olabilir"63 şeklinde karşılık verilmiştir.

Kur'ân ve hadislere göre ilk insanın Hz. Âdem olduğu konusunda herhangi bir şüphenin bulunmadı̆̆ı, 64 tüm dinlerin bu konuda müttefik olduğu, ${ }^{65} \mathrm{~Hz}$. Âdem'den önce kendi cinsinden kimsenin olmadığ ${ }_{1}{ }^{66}$ ondan önce Âdemler'in olduğunu söylemenin Kur'ân âyetlerini inkâr manasına geldiği, ${ }^{67} \mathrm{~Hz}$. İsa'nın durumunun $\mathrm{Hz}$. Âdem'in durumuna benzetilmesinin ${ }^{68}$ yaratmanın olağanüstü bir şekilde gerçekleștiğini, daha önce buna benzer bir örneğin olmadığını, ${ }^{69} \mathrm{~Hz}$. Âdem'in evrimleşerek gelmediğini ve babasız yaratıldığını gösterdiği,70 Kur'ân'ın Hz. Âdem'den ayrı ikinci üçüncü veya başka bir Hz. Âdem'den bahsetmediği ${ }^{71}$ ifade edilmiştir. Hz. Âdem'in ilk insan olup olmadığı vb. yaratılışla ilgili detaylar Kur'ân'da sarih bir şekilde verilmediği ${ }^{72}$ için akide konusu değildir. ${ }^{73}$ Dolayısı ile yaratılışla ilgili farklı fikirlerin, Hz. Âdem'den önce Âdemlerin olduğunu söylemenin âyetleri inkârla bir ilgisi bulunmamaktadır. Bu tür düşüncelerin tekfire değil tenkide konu olmaları gerektiğine inanmaktayı.

Tâhâ sûresi 20/116-121. âyetlerde hitabın iki kişiye yapıldı̆̆ı ve yasak ağaçtan sadece iki kişinin yediğinin anlatıldığı, mecazi anlatımların bazı sayılarda geçerli olduğu ama iki sayısında geçerli olmadığı, bunun da Âdem ve Havvâ'dan önce

Hüseyin Atay, “Allah'ın Halifesi: İnsan”, Ankara Üniv., İlahiyat Fak. Dergisi 18 (1970), 75.

Avnullah Enes Ateș, “Kur'an'da İnsanların Yaratılıșı Meselesi”, Hitit Üniv., İlahiyat Fak. Dergisi $15 / 30(2016 / 2), 364$

Ahmet Bedir \& Arif Sarsılmaz, "Hz. Âdem'in Boyu”, Harran Üniv., İlahiyat Fak. Dergisi, 4 (1998), 133; Erdem, Hazreti Âdem (İlk İnsan), 116, 118, 133.

Abdulmecit Okçu, "Kur'an ve Evrim Açısından Canlıların Oluşumu”, EKEV Akademi Dergisi 17/56 (2013), 174.

Meryem 19/67. Erdem, Hazreti Âdem (İlk Insan), 115.

Erdem, Hazreti Âdem (ílk İnsan), 132.

Âl-i İmrân 3/59.

Erdem, Hazreti Âdem (İlk Insan), 115-118.

Bahattin Dartma, "Kur'an Bağlamında İlk İnsan ve Nübüvvet-Fıtrat İlișkisi”, Dinbilimleri Akademik Araştırma Dergisi 1 (2006/6), 10-11; Yunus Emre Gördük, "İlk İnsan Nesli Nasıl Devam Etti? Ensest İlişki İddiası Üzerine Eleştirel Bir Analiz”, Usul İslam Araştırmaları 29 (2018), 73. Abdullah Aydemir, Tefsirde İsrâiliyyât (İstanbul: Beyan Yay., 2015), 135-137.

Süleyman Ateș, Yüce Kur'an'ın Çağdaş Tefsiri (İstanbul: Yeni Ufuklar Neşriyat, 1988), 2/190-192. Taslaman, Bir Müslüman Evrimci Olabilir mi, 97. 
insanların olmadığına işaret ettiği, ${ }^{74}$ mevcut insanlığın atası Âdem'den önce binlerce Âdem'in gelip geçtiği görüşünü kabul etmek ve reddetmek için elimizde yeterli delilin bulunmadığı, Kur'ân'ın insanların Hz. Âdem ve Havvâ'dan geldiğini söylediği ancak Hz. Âdem'den önce insanların yaşadığı konusunda bilgi vermemiş olmasının böyle nesillerin gelmediğini göstermediği belirtilmiştir. ${ }^{75}$

Kur'ân'da Hz. Âdem ile eşinden söz edilirken fiil ve zamirlerin çoğunlukla ikil/tesniye formunda geldiği, âyetlerin açık ifadelerinin Hz. Âdem'in ilk yaratılan ve ruh üflenen ilk insan olduğunu gösterdiği, Hz. Âdem'in ilk yaratılan insan olmadığı ve Kur'an'ın, beșer cinsinin evrimleșerek/tekâmül ederek "âdemleștiği" iddiasını onaylamadığı ifade edilmiştir. ${ }^{76}$

İnsanlı̆̆ın ilk atası Âdem'in ne zaman yaratıldığı hususundaki Tevrat ayetlerinin ve çeşitli isrâili görüşlerin veya Âdem'den önce birçok Âdemlerin olduğu rivâyetlerinin sübut ve delalet bakımından kat'i hiçbir delile dayanmadığ ${ }_{1}{ }^{77}$ Allah'ın, Hz. Âdem'i dünyadaki hayatının ilk gününde bir insan olarak yarattığı ve hayatının başlangıcında ona idrak ve şuur verdiği belirtilmiştir. ${ }^{78}$

"O ki; yarattığı her şeyi güzel yapmış, insanın yaratılışına da balçıktan başlamıştır. Sonra onun neslini çok az miktardaki bir sudan süzülmüş bir maddeden meydana getirmiştir"79 âyeti ve başka birçok âyet ilk insanın Hz. Âdem olduğunu ve insanlığın ondan çoğaldığını göstermektedir. ${ }^{80}$

Hz. Âdem'i ilk insan kabul edenler aynı zamanda onu ilk peygamber de kabul etmişlerdir.81 Al-i İmrân 3/33. âyet Hz. Âdem'in seçildiğine ve ilk peygamber olduğuna delildir. ${ }^{82}$ Kur'ân'da Hz. Âdem'in rabbinden kelimeler aldığının ${ }^{83}$ ifade edilmesi de peygamber olduğunun bir başka delilidir. ${ }^{84} \mathrm{~Hz}$. Âdem'in ruh üflenerek, akıl, irade ve vicdan sahibi kılınarak seçildiği, nebi veya resul olduğunu açıkça ifade eden herhangi bir âyetin bulunmadığı, ${ }^{85}$ yaratılışın bidâyetinde bahsedilen Hz. Âdem ve Havvâ'nın insanlığın ataları oldukları ancak elçilik vazifesi verilen Âdem'in başka biri olduğu iddia edilmiş̧ ise de bunun herhangi bir dayanağı ve tutarlılığı bulunmamaktadır. İlk elçinin kim olduğu şeklindeki bir süale Hz. Peygamber'in;

Şimşek, Yaratılış Olayı, 50-51.

Şimşek, Yaratılış Olayı, 56; Ateş, Yüce Kur'an'ın Çağdaş Tefsiri, 2/190-192.

Gördük, “İlk İnsan Nesli Nasıl Devam Etti? Ensest İlișki İddiası Üzerine Eleștirel Bir Analiz", 70;

Ateş, “Kur'an'da İnsanların Yaratılıșı Meselesi”, 361. (Makalelerde daha başka deliller de ileri sürülmüştür.)

Cerrahoğlu, "Kur'an'da İnsanın Yaratılıș Sahnesinin Düşündürdükleri”, 95.

Okçu, "Kur'an ve Evrim Açısından Canlıların Oluşumu”, 174.

es-Secde 32/7-8.

Şimşek, Yaratılış Olayı, 30.

Muhsin Demirci, Kur'an'ın Ana Konuları (İstanbul: İFAV Yay., 2008), 85.

Dartma, "Kur'an Bağlamında İlk İnsan ve Nübüvvet-Fıtrat İlişkisi”, 12; Güngör Karauğuz, Âdem'in Cocukları Çiviyazılı Kaynaklar, Tevrat, Inciller ve Kur'ân'a Göre (Konya: Çizgi Yay., 3. Basım, 2017), 51; Bolay, "Âdem", 359; Sarmış, Kur'ân'a Göre Insan'ın Yaratılması ve Çoğalması, 52; Öztürk, Kur'an ve Yaratılış, 172.

el-Bakara 2/37.

Bolay, "Âdem", 359.

İslamoğlu, Kur'an ve Tabiat Ayetleri Işı̆̆ında Yaratılış ve Evrim, 195.

Okumuş, Eşref'ten Esfel'e Insanın Serüveni, 199. 
"Âdem'dir" șeklinde cevap verdiği belirtilmiștir. ${ }^{87}$ Her ne kadar konuyla ilgili bazı farklı fikirler ileri sürülmüş olsa da kanaatimizce Kur'ân ve sahih hadislerin verileri, Hz. Âdem'in ilk insan ve ilk peygamber olduğunu göstermektedir. 88 "Hz. Âdem'in ilk peygamber olduğu ama ilk insan olmadığı” söyleminin ${ }^{89}$ Kur'ân ve hadislere aykırılık arz ettiğini, Kur'ân âyetlerini te'vîl etmek suretiyle insanın kökeninin insan olmayan varlıklara bağlanmasının hem dine hem bilime ters düştüğunü düşünmekteyiz. ${ }^{90}$

\section{Hz. Âdem'in Yaratılış Kıssası ve Kronolojisi}

İlk insanın nasıl yaratıldığı, insanlığın nasıl çoğaldığı ve nasıl bir süreçten geçtiği akıllarda daima bir soru işaretidir. Kur'ân'da, Allah'ın yaratmaya "ol"91 demekle başladığı, ${ }^{92}$ üzerinden anılmaya değer herhangi bir şey olmadığı uzun bir süre geçtikten sonra insanın ${ }^{93}$ yerden bitirildiği ${ }^{94}$ su, toprak, çamur vs. ${ }^{95}$ aşamalardan geçtiği, ${ }^{96}$ tek nefis haline geldikten sonra eşinin de var edildiği ve her ikisinden ${ }^{97}$ anne rahminde, üç katman karanlığın içinde, art arda yaratılış aşamalarından geçirilerek insanların çoğaltıldığ $1^{98}$ ifade edilmektedir. İnsanın yaratılışının Kur'ân'da, elementer yaratılış süreci, biyolojik yaratılış süreci, embriyolojik gelişim süreci ve biyolojik gelişim süreci bağlamında işlendiği, ${ }^{99}$ elementer yaratılış sürecinin insanın hammaddesine atıf olduğu ve tüm bu aşamaların toprak ve su olmak üzere iki asli unsura delalet ettikleri, ${ }^{100}$ Âdem ve tüm insanların orjininin toprak olduğu, ${ }^{101}$ Âdem'in çamurdan, soyunun ise sudan yaratıldığı ifade edilmiştir. ${ }^{102}$

İslamoğlu, Kur'ân'ın her canlı varlığın sudan yaratıldığını söylediğini, hayat sürecinin tek hücreli mikroskobik canlılardan başlayıp insanla taçlandığını, insanın değil insansının/beşerin sudan yaratıldığını ${ }^{103}$ âlemlerin tamamının insanın biyolojik soy ağacını oluşturduğunu, Allah'ın Âdem'i homo türlerinin içinden seçtiğini, insanın bir şey olarak anılmaya değer olmadı̆̆ı uzun döneme beșer/homo döneminin de dâhil olduğunu, insanların atası olan Homo sapiens dışında diğer homo türlerinin soyunun 
kesildiğini, Âdem'in topraktan yaratıldığını söyleyen âyetin bütün bir insanlığın topraktan yaratıldığını söyleyen birçok âyetle birlikte okunması gerektiğini, topraktan yaratılmanın elementer yaratılışa ve tüm gıdaların kaynağının toprak oluşuna atıf olduğunu, İnsan 76/1-2. âyetlere dayanarak Hz. Âdem'in insan olması hasebiyle topraktan değil, her insan gibi nutfeden yaratıldığını, Yunus, 10/4. âyetine dayanarak insanoğlunun yaratılışının başlangıcında işleyen süreçlerin son insana kadar aynen işlediğini/işleyeceğini, A'raf, 7/11. âyette Âdem isminin Âdemoğlu anlamında kullanıldığını, Al-İmran, 3/59. âyette İsa'nın durumunun Âdem'in durumuna benzetilmesinin aynı yaratılış sürecinin/ana karnı sürecinin onun için de geçerli olduğunu gösterdiğini ifade ederek ${ }^{104}$ Âdem'in ilk insan değil sembolik ata olduğunu ve topraktan değil nutfeden yaratıldığını iddia eder. ${ }^{105}$ Ateş'in konuyla ilgili düşünceleri ise şu şekildedir: "İlk insan ve hatta bütün canlılar esas itibariyle topraktan yaratılmıştır. Sonra insan nutfeden yaratılma safhasına getirilmiştir. Âdem de menşe'i toprak olan nutfe'den yaratılmıștır. Ancak bu nutfe bir insandan gelmemektedir. Âdem, insanla hayvan arasındaki sınır canlının nutfesinden yaratılmıştır."106

Cerrahoğlu bu ve buna benzer iddialara karşın șunları söylemektedir: "Onun oluşumu ve mahiyeti bizce meçhuldür. İlk insan olan Âdem'i meydana getiren nutfe, tini lazib, nutfe-i emşac bir insan bedeninde teșekkül etmemiş ve insan bedeninden süzülüp çıkmamıştır. O iradeyi ilahiyye ile nutfeye dönüşmüş bir balçıtan yaratılmıştır. Genellikle insanın yaratılışından bahsedilirken onun topraktan nasıl vücuda getirildiği ve onun toprak mayasından (nutfeden) yaratıldığı anlatılıyor. Nutfe ne şekilde olursa olsun, topraktan alınan gıdanın hulasasıdır. İnsan yemiş olduğu nebatlar ve hayvanlar ile onu bünyesine ithal etmektedir."107

Kur'ân, beşerin/insanın yaratılışını iki farklı boyutta birçok âyette işlemektedir. İlk boyut, beşerin toprak, çamur ve sudan yaratılmasıyla, ikinci boyut ise anne rahminde meni ve nutfenin alakaya, alakanın mudğaya dönüşmesiyle aşama aşama vücuda getirilmiş olmasıyla ilgilidir. ${ }^{108}$ Kur'ân'da "çamurdan yaratılmanın"109 "başlama" (bedee) aşaması olarak ifade edilmesi doğal olarak başka aşamaları da akla getirmektedir. ${ }^{110}$ İlk insanın topraktan yaratılmasının 6 âyette, çamurdan yaratılmasının 6 âyette, çamurun nitelikleri ve farklı safhalarının 6 âyette işlendiği, ana karnında da çocuğun 6 safhadan geçtiği, kâinatın 6 safhada yaratıldığı ve bunun tesadüf olmadığı ifade edilmektedir. ${ }^{111}$ Kur'ân'da insanın yaratılışından bahseden

\footnotetext{
104 İslamoğlu, Kur'an ve Tabiat Ayetleri Işığında Yaratılış ve Evrim, 131, 141-146, 160-171, 191-193, 225, 237.

105 İslamoğlu'nun görüşlerini reddi için bk. Sarmış, Kur'ân'a Göre İnsan'ı́n Yaratılması ve Çoğalması, 112-125.

Ateș, Kur'an-ı Kerim'e Göre Evrim Teorisi, 133.

Cerrahoğlu, Kur'an'da İnsanın Yaratılıș Sahnesinin Düșündürdükleri, 89.

Öztürk, Kur'an ve Yaratılış, 149.

es-Secde 32/7.

Taslaman, Bir Müslüman Evrimci Olabilir mi, 73.

Celal Yeniçeri, Uzay Ayetleri Tefsiri (İstanbul: Erkam Yay., 1995), 290-291; Şimşek, Yaratılış Olayı, 30.
} 
âyetlerde bir de maddeden ruhsallığa doğru bir tekâmül sürecinin işlediği anlatılmaktadır. ${ }^{112}$

Kur'ân'da insanın elementer yaratılış süreci şu şekildedir:113

1- الماءMa', su: Enbiyâ, 21/30; Nûr, 24/45; Furkân, 25/54.

2- تراب Turâb, toprak: Âl-i İmrân, 3/59; Kehf, 18/37; Hac, 22/5; Rûm, 30/20; Fatır, 35/11; Mü'min, 40/67.

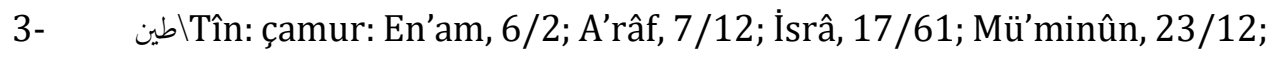
Secde, 32/7; Saffât, 37/11; Sâd, 38/71, 76.

4- السلالة من طين Sülâle min tîn, süzülmüş çamur, çamurdan bir öz: Mü’minûn, $23 / 12$.

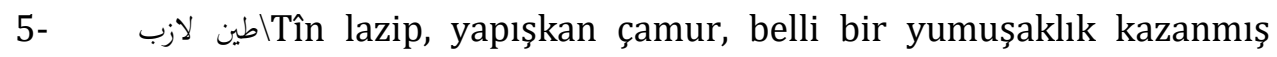
şekillendirilebilir yapışkan bir toprak: Saffât, 37/11.

6- صلصال /Salsâl, pişmemiş kuru çamur, dokununca ses çıkarma özelliğine sahip pişmiş kuru çamur, مماء مسنون/Hamain mesnun/değişken cıvlk ve kokulu çamur, yoğunlaşmış çamur, çamurun hava ile girdiği değişiklikle oluşan kara balçı: Hicr, 15/26, 28, 33.

7- الفلصال كالفخار/Salsâl kel fahhâr, pişmiş çamur, ateşin tesiri ile kiremit haline gelmiş pişik çamur: Rahmân, 55/14.

8- نفخ /Nefh, Ruhun üflenmesi: Sâd, 36/71-72.

Kur'ân'da insanın biyolojik ve embriyolojik yaratılış süreci şu şekildedir:114

1- نفس واحدة/ Nefsi vâhide, ilk insan veya ilk öz: Nisâ, 4/1; En'âm, 6/98; A'râf, 7/189; Zümer, 39/6.

2- نطفالمutfe, zigot: Nahl, 16/4; İnsân, 76/2; Kehf, 18/37; Hac, 22/5; Mü'minûn, 23/13; Fâtır, 35/11; Mü'min, 40/67; Kıyâmet, 75/37-38; Abese, 80/19.

3- علقة/Alaka, embriyo: Alak, 96/2; Hac, 22/5; Mü'minûn, 23/14; Mü’min, 40/67; Kıyâmet, 75/37-38.

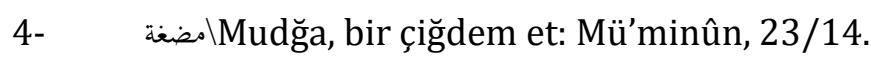

5- اعظام أعâm, kemik: Mü’minûn, 23/14.

112 Şaban Ali Düzgün, Sarp Yokuşun Eteğinde Insan (Ankara: Otto Yay., 2016), 27.

113 Okuyan, Kıssalar Ne Söyler Yaratılış ve Hz. Âdem I, 61. İnsanın elementer yaratılış aşamalarının farklı sıralaması için bk. Yakıt, Kur'ân'ı Anlamak, 59; M. Sait Kavşut, "Kur'an'da İnsanın Yaratılıș Așamaları Te'vilat Ekseninde Bir Değerlendirme”, Şarkiyyat İlmi Araștırmalar Dergisi 7 (2012), 289-300; İslamoğlu, Kur'an ve Tabiat Ayetleri Ișığında Yaratılış ve Evrim, 134-137; Sarmıș, Kur'ân'a Göre Insan'ın Yaratılması ve Çoğalması, 113; Düzgün, Sarp Yokușun Eteğinde Insan, 30; Erdem, Hazreti Âdem (Illk Insan), 115.

114 Okuyan, Kıssalar Ne Söyler Yaratılış ve Hz. Âdem I, 61. İnsanın yaratılışı için bk. M. Ali el-Bâr, Kur'ân'ı Kerîm ve Modern Tıbba Göre Insanın Yaratılışı, çev. Abdülvehhap Öztürk (Ankara: TDV Yay., ts). 
6- $\quad$ الم Lahm, et: Mü'minûn, 23/14.

7- خلق آخر|Halk ahar, bambaşka yaratılış: Mü’minûn, 23/14.

Hz. Âdem kıssası, altı tanesi Mekki üç tanesi Medeni olmak üzere toplamda 9 sûrede ve 70 küsur âyette işlenmektedir. ${ }^{115}$ Kıssanın nüzul sıralamasına göre kronolojik düzeni sırasıyla şu şekildedir: 1 . Sâd, 38/71-85; 2 . A'râf, 7/11-27; 3. Tâhâ, 20/115-123; 4. İsrâ, 17/61-65; 5. Hicr, 15/26-43; 6. Kehf, 18/50; 7. Bakara, 2/30-39; 8. Âl-i İmrân, 3/33, 59; 9. Mâide, 5/27-31.

Âdem kıssasının işlendiği 9 sûrenin 7'sinde meleklere verilen secde emrinden ve şeytanın bu emre itaat etmemesinden, hatasında israrcı olmasından bahsedilmesi kıssanın hedefinin tarihi malumat vermek değil mesaj vermek olduğu anlaşılmaktadır. Farklı sûrelerde birçok âyette aktarılan Âdem kıssasını kronolojik tasnife tabi tuttuğumuzda Hz. Âdem'in yaratılışı ve hayatı ile ilgili tarihi bilgilerin verilmediğini, verilen bilgilerin günahtan sakındırmaya dönük olduğunu ve ibret amaçlı zikredildiklerini görmekteyiz. Kanaatimizce kıssada Hz. Âdem'in hatası ve şeytanın sapması üzerinden tüm insanlığa; kendine çeki düzen vermeleri gerektiği aksi takdirde Âdem ve şeytan gibi kazanımlarını kaybedecekleri dersi verilmektedir. Ali Şeriati'nin kıssadan çıkardığı; “Biz hepimiz Âdemiz. Cennetse şu hayattır. Herkes o yasak ağacın meyvesinden yediği ölçüde kendisini yeryüzünün daha fazla sürgünü ve zamanın daha fazla yabancısı olarak görür"116 mesajı meramımızı tam da özetlemektedir.

\section{Tek Nefis ve Kadının/Havvâ'nın Yaratılıșı}

Arap dil sözlüklerinde nefs/نفس kelimesi, "ruh, kan, ceset, kişi, kurtarmak, göz, hakikat, can, canlı"; 117 zevc/زوج) kelimesi ise "tekin zıddı, tek, çeşit, koca, eş, birleştirme, denk"118 anlamlarına gelmektedir. Ayrıca kan için "nefs", hayızlı kadına "nefsâ"”, solunan havaya da "nefes" denir. ${ }^{119}$ Nefs sözcügüu, müennes olmakla birlikte müzekker için, zevc ifadesi de müzekker bir yapıda olmakla birlikte müennes için kullanılmaktadır.120 Kur'ân'da "nefs" kelimesi genelde "insanın kendisi, kişi”"

\footnotetext{
115 Kissa sırayla şu sure ve ayetlerde ișlenmektedir: Sâd 38/71-85; el-A'râf 7/11-27; Tâhâ 20/115123; el-İsrâ 17/61-65; el-Hicr 15/26-43; el-Kehf 18/50; el-Bakara 2/30-39; Âl-i İmrân 3/33, 59: el-Mâide 5/27-31.

116 Ali Şeriati, Çöle İniş (Hubut-Kevir), çev. Hicabi Kırlangıç \& Derya Örs (Ankara: Fecir Yay., 2015), 134.

117 Ferâhîdî, Kitâbu'l-Ayn, 839; Cevherî, Mu'cem es- Sihâh, 1058-1059; Firuzâbâdî, el-Kâmusu'l- muhît, 1303-1304; Ragib el-İsfehânî, el-Müfredât fî garîbi'l-Kur'ân, 503.

118 Ferâhîdî, Kitâbu'l-Ayn, 341; Cevherî, Mu'cem es- Sihâh, 462-463; Firuzâbâdî, el-Kâmusu'l- muhît, 579; Ragıb el-İsfehânî, el-Müfredât fî garîbi'l-Kur'ân, 220-221.

119 Ebû Muhammed Abdullâh bin Müslim ibn Kuteybe ed-Dineverî, Tefsîru garîbu'l-Kur'ân, thk. Seyyid Ahmed Sakr (Beyrut: Mektebetü'l-Alemiyye, 2007), 25; Firuzâbâdî, el-Kâmusu'l- muhît, 1303-1304; Cevherî, Mu'cem es- Sihâh, 1058-1059.

120 Kurtubî, Ebû Abdullah Muhammed bin Ahmed el-Ensârî, el-Câmi' lî ahkâmi'l-Kur'ân, thk. Muhammed İbrahim el-Hafnevî-Mahmûd Hâmîd Osmân (Kahire: Dâru'l-Hadîs, 2002), 3/7; Züleyha Birinci, "Nefs-i Vâhide' İfadesinden Hareketle Kadının Yaratılıșı Hakkında Bir Değerlendirme", Marmara Üniv. İlâhiyat Fak. Dergisi 47 (2014), 159.
} 
anlamında birçok yerde kullanılmıştır. ${ }^{121}$ Nefsin insan içinde kötü dürtüleri ifade ettiği bilgisi ise sonradan kazanılmış bir anlamdır.

Kur'ân'da birçok âyette ${ }^{122}$ geçen ve insanlığın ilk yaratılışına dikkat çeken "nefs-i vâhide" ve ilk kadının yani Hz. Havvâ'nın nasıl yaratıldığı İslâm ilim tarihinde tartışma konusudur. Havvâ'nın erkeğin neresinden yaratıldığı ve ismi Kur'ân'da yazmadığı gibi tek nefisten yaratılmayı ifade eden âyetlerin tümünde de "nefsi vâhide"nin Âdem olduğu beyan edilmemiştir.123 İlk dönem âlimlerinin büyük çoğunluğu, Nisâ 4/1. âyet başta olmak üzere birçok âyette geçen "nefs-i vâhide" ile $\mathrm{Hz}$ Âdem'in, "zevceha” kelimesi ile Hz. Havvâ'nın kastedildiğini, Havvâ'nın Âdem'in kaburga kemiğinden yaratıldığını söylerken ${ }^{124}$ son dönem âlimleri ise "nefs-i vâhide" ile insanlığın yaratıldığı “özün” kastedildiğini ve Havvâ'nın Hz. Âdem gibi aynı “öz”den yaratıldığını ifade etmişlerdir. ${ }^{125}$ İlk dönem Şia tefsirlerinde Ebu Ca'fer el-Bakır’ın, Havvâ'nın Adem'den değil Adem'in yaratıldığı topraktan yaratıldığı görüşünde olduğu ifade edilmiştir.126

Okuyan; "nefs-i vâhide" ile Hz. Âdem'in, "zevcehe" ile eşi Havvâ'nın kast edilmediğini, "tek nefs" ifadesinin, ilk hücreye ve eşine kaynaklık ettiğini, ilk insanın yaratıldığı kaynak olan "nefs-i vâhide"nin eşinin de yaratılış kaynağı olduğunu, orada bir mitoz bölünmenin yaşanmış olabileceğini, "tek nefis", "zeker" ve "ünsa" kelimelerinin hücre türünün erkek ve dişisini gösterdiğini, "nefs-i vâhide"'nin insanın biyolojik varlık aşamasının ilkini oluşturduğunu söyler.127 Sarmış, "tek nefis" ifadesinin ilk yaratılan ve insanın biyolojik yaratılışının ilk halkasını oluşturan hücre olmadığını, En'âm 6/98. âyette belirtildiği gibi erkek ve kadının sulbünde karar kılmış olan sperm ve yumurtanın ana rahminde buluşup döllenerek doğuncaya kadar emanet bırakılan "emriyo" olduğunu ifade etmiştir. ${ }^{128}$

121 el-A'raf 7/42, 188, Lokmân 31/34; el-Fecr 89/27 vs. Ragıb el-İsfehânî, el-Müfredât fí garîbi'lKur'ân, s. 503;

122 en-Nisâ, 4/1; el-En'âm 6/98; el-A'râf 7/189; Lokmân 31/28; ez-Zümer 39/6; er-Rûm 30/21; enNahl 16/72; el-Hucurât 49/13.

123 Reşîd Rızâ, Tefsîru'l-Kur'âni'l-Hakîm, 5/263-266; Tâhir bin Âşûr, Tefsîru't-Tahrîr ve't-Tenvîr, 1/429; Şimşek, Yaratılış Olayı, 58; Caner Taslaman, Evrim Teorisi Felsefe ve Tanrı (İstanbul: İstanbul Yay., 2016), 267; a. mlf. Bir Müslüman Evrimci Olabilir mi, 91.

124 Taberî, Câmiu'l-beyân an te'vîli âyi'l-Kur'ân, 1/301-302, 3/280-282; Mâturîdî, Tevilâtü Ehli'sSünne, 3/3; Ebû Ca'fer Muhammed bin el-Hasen et-Tûsî, et-Tibyân fí tefsîri'l-Kur'ân, thk. Ahmed Habîb Kasîr el-Âmîlî (Beyrut: Müessesetü'l-A'lemî li'l-Matbuât, 2013), 3/7; Ebû Alî el-Fazl bin Hasen bin el-Fazl et-Tabresî, Mecmau'l-beyân fî tefsîri'l-Kur'ân, thk. İbrahim Şemsuddîn (Beyrut: Dâru'l-Kütübi'l-İlmiyye, 1997), 3/5-6; Kurtubî, el-Câmi' lî ahkâmi'l-Kur'ân, 3/7; Nasiruddîn, Ebû Saîd Abdullâh bin Ömer bin Muhammed eș-Șirâzî el-Beyzâvî, Envâru't-tenzîl ve esrâru'tte'vîl/Tefsîru'l-Beyzâvî (Beyrut: Dâru'l-Kütübi'l-İlmiyye, 2002),1/199; Nesefi, Medâriku't-tenzîl, 207; Ebû'l-Kâsım Cârullah Mahmûd bin Ömer bin Muhammed ez-Zemahșerî, el-Keșşâfa an hakâiki ğavâmizi't-tenzîl ve uyûnu'l-ekâvîl fî̀ vucûhu't-te'vîl, thk. Muhammed Abdusselâm Şâhîn (Beyrut: Dâru'l-Kütübi'l-İlmiyye, 1995), 1/451; Şimşek, Yaratılış Olayı, 57.

125 Özdeş, Kur'an ve Cinsiyet Ayırımcılığı, 74; Demirci, Kur'an'ın Ana Konuları, 97.

126 Tûsî, et-Tibyân fî tefsîri'l-Kur'ân, 3/7; Tabresî, Mecmau'l-beyân fî tefsîri'l-Kur'ân, 3/6; Tâhir bin Âșûr, Tefsîru't-Tahrîr ve't-Tenvîr, 2/214-215.

127 Okuyan, Kıssalar Ne Söyler Yaratılış ve Hz. Âdem I, 74-82.

128 Sarmış, Kur'ân'a Göre İnsan'ın Yaratılması ve Çoğalması, 85. 
Âyetlerde geçen "tek nefis" ile zigot'un anlatıldığı, âyette zigottan yaratılışın tarifinin yapıldığı ve "tek nefsin" rahimde döllenen tek zigot olduğu, ${ }^{129}$ "nefs-i vâhid"nin insanın emriyolojik yaratılış sürecini başlatan sperm hücresi, insanın biyolojik yaratılış sürecini başlatan ilk ve tek hücre olduğu,130 "tek nefis" ifadesinin insanı meydana getiren prensip, su veya nutfe olabileceği131 ileri sürülmüştür. Ateş, Kur'ân'da tek nefis ile Âdem'in kastedildiğinin yazmadığını, âyetteki nefisten kastın Âdem değil insanın aslı olan ilk canlı olduğunu, insanı var etmek üzere oluşturulan bu canlının önce eşsiz üreme yoluyla başka varlıklara veya hayvanlara dönüşmeksizin kendi istikameti üzerinde evrimleşip/tekâmül edip eşli üreme aşamasına geldiğini ve bundan sonra birçok erkek ve kadının var edildğini iddia eder.132 Tuksal'ın yaptığı bir nakle göre, "nefs" kelimesi, insan neslinin biyolojik özü olan bir "canlı öz" şeklinde anlaşıldığında, bu canlı öz erkek ve dişi olarak şekillenmekte, bir tek nefisten/özden eşi de var edilerek bir çift canlı öz yaratılmış olmaktadır. Bu canlı öz, insan olma süreci tamamlanmış bir erkek kişi değil, erkek olma potansiyelini de dişi olma potansiyelini de içinde barındıran, temel bir insanlık potansiyelidir. ${ }^{133}$

Kadının erkekten yaratılması ile ilgili birçok hadis gelmiştir. Bu hadisler genelde, "kadın kaburga kemiği gibidir" ve "kadın kaburga kemiğinden yaratılmıştır" şeklinde iki farklı varyantta gelmektedir. ${ }^{134}$ Kadının erkeğin kaburga kemiğinden yaratıldığı bilgisi Tevrat'ta da geçmektedir. ${ }^{135}$ Her ne kadar kadının Âdem'in kaburgasından yaratıldığını reddedecek herhangi bir belgenin olmadığı ifade edilmiş ise de ${ }^{136}$ çağdaş kimi araştırmacılar tarafından hadisler Ehl-i Kitâb'a ait metinlerle örtüşmesinden ${ }^{137}$ dolayı israiliyât olarak değerlendirilmişlerdir. ${ }^{138}$ Carullah, kadının erkeğin eğri sol kaburgasından yaratıldığını söylemenin bir gaflet olduğunu, "min enfüsikum"139 gibi ifadelerin insanın aceleden/aceleci yaratılması ${ }^{140}$ ile aynı minvalde değerlendirilmesi gerektiğini ${ }^{141}$ ve müfessirlerin, vehimlerini semavi nasların önüne

Süleyman Aksoy, Kur'an'ın Embriyolojik Sirları (İstanbul: Kayahan Yay., 2004), 93-128.

İslamoğlu, Kur'an ve Tabiat Ayetleri Ișığında Yaratılış ve Evrim, 244-245.

Yakıt, Kur'ân'ı Anlamak, 71.

Ateș, Yüce Kur'an'ın Çağdaş Tefsiri, 2/190-192.

Tuksal, Kadın Karşıtı Söylemin İslâm Geleneğindeki İzdüșümleri, 77.

Ebû Huseyn Müslim bin Haccâc el-Kușeyrî, Sahîhu Müslim, thk. Ahmed Zehve-Ahmed İnaye (Beyrut: Dâru'l-kitâbi'l-arabî, 2004), "Rada", 59, 60, 65; Ebû Abdullâh Muhammed bin İsmâîl elBuhârî el-Cu'fî, el-Câmiu's-Sahih, thk. Muhammed Nizâr Temîm-Heysem Nizâr Temîm (Beyrut: Dâru'l-Erkâm, ts.), "Nikâh", 79, 80; "Enbiyâa", 1; Ebû İsâ Muhammed bin İsâ bin Sevre et-Tirmîzî, Sünenü't-Tirmîzî (Beyrut: Dâru'l-Ma'rife, 2002), "Talak", 12; Ebû Abdullâh Muhammed bin Yezîd el-Kazvînî İbn Mâce, Sünenü İbn Mâce, thk. Halîl Me'mûn Șihâ, 2 Cilt (Beyrut: Dâru'l-Ma'rife, 1998), "Tahâre", 77.

Tekvîn, 2/21-23.

Erdem, Hazreti Âdem (İlk Insan), 148.

Öztürk, Kur'an ve Yaratılış, 160.

Okuyan, Kıssalar Ne Söyler Yaratılıș ve Hz. Âdem I, 80; Cemal Ağırman, Kadının Yaratılıșı İlgili Rivayetler Bağlamında Yeni Bir Yaklaşım (İstanbul: Rağbet Yay., 2001), 275-276; Ali Osman Ateş, Hadis Temelli Kalıp Yargılarda Kadın (İstanbul: Beyan Yay., 2000), 270, 253-283; Aydemir, Tefsirde İsrâiliyyât, 311; Taslaman, Bir Müslüman Evrimci Olabilir mi, 89; Sarmıș, Kur'ân'a Göre Insan'ın Yaratılması ve Çoğalması, 68. er-Rûm 30/21; en-Nahl 16/72.

el-Enbiyâ 21/37.

Bk. Reşîd Rızâ, Tefsîru'l-Kur'âni'l-Hakîm, 1/231-232; 5/263-265. 
geçirdiklerini söyler. ${ }^{142}$ Kanaatimizce hadisler hakikat değil mecaz ifade etmektedir. ${ }^{143}$ Medine'deki kadın karşıtı yaygın Yahudi kültürü benzetme ifadeleri ile kadının lehine ıslah edilmiştir.

Havvâ'nın Hz. Âdem'den yaratılmasının bir eksiklik veya aşağılanma sebebi olmadığı, kadının eğe kemiğinden yaratılmış olmasının yaratılıştan eğri olduğu ve düzelmeyeceği anlamına gelmediği, kadının kalbi saran eğe kemiğinden yaratılmış olmasının kadın erkek arasındaki sevgi bağına işaret ettiği, hadislerin genelde kadınlara iyi davranma bağlamında geldiği ve kadının erkekten yaratılmasının kadın ve erkeğin birbirini tamamlayan bir bütünün parçaları anlamına geldiği yorumları da yapılmıştır. ${ }^{144}$

"Nefs" kelimesinin Kur'ân'daki kullanımı göz önünde bulundurulduğunda "nefs-i vâhide" ifadesinin "tek kişi" anlamına geldiği söylenebilir. "Nefs" kelimesi Kur'ân'da hiçbir yerde "öz” anlamında kullanılmamıştır. Dolayısı ile "tek nefis/kişi” ile kastedilenin Hz. Âdem olduğunu, 145 "zevceha" ifadesi ile eşi Havvâ'nın ifade edildiğini ve insanlığın bu iki kişiden çoğaldığını söyleyebiliriz. Ĕger burada kastedilen "nefs" iddia edildiği gibi Hz. Âdem değil de "öz"146 ise o halde özün eşinden bahsetmemiz gerekecektir ${ }^{147}$ ki bu da mümkün değildir.

Kanaatimizce burada asıl sorun "min" edatının tefsiridir. Müfessirlerin geneli buradaki min edatını "teb'iziyye" olarak almışlardır. ${ }^{148}$ Hâlbuki "min" edatı hem "teb'iz" hem "cins" ifade etmektedir. ${ }^{149}$ Ebû Müslim el-İsfehânînin (öl. 322/934), "halaka minhâ zevcehâ" ifadesini "eşini onun cinsinden yarattı" şeklinde açıklamış olması önemlidir. ${ }^{150}$ Âyette kadının erkekten yaratıldığına değil, önce erkeğin sonra da onu tamamlar nitelikte, onun gibi özelliklere sahip bir şekilde eşinin yaratıldığına vurgu yapılmaktadır. "Sizinle min enfüsikum/aynı cinsten eşler yaratmıştır"151 âyetlerinin "size min enfüsikum/kendi içinizden peygamber göndermiştir"152 âyetleri ile aynı minvalde değerlendirilmesi gerektiğine inanmaktayız. Bu âyetlerin hepsinde geçen "min enfüsikum" ifadeleri "sizin benzeriniz, sizin gibi biri" anlamına gelmektedir. ${ }^{153}$ Tüm bu açıklamaların ışı̆̆ında kadının erkeğin cisminden değil

142 Musa Carullah Bigiyef, Hatun, çev. Mehmet Görmez (Ankara: Otto Yay., 2014), 40.

143 İbrahim H. Karslı, Kur'an Yorumlarında Kadın (İstanbul: Rağbet Yay., 2003), 81; Sarmıș, Kur'ân'a Göre İnsan'ın Yaratılması ve Çoğalması, 75; Muhsin Demirci, Kur'ân Tefsirinde Farklı Yorumlar, (İstanbul: İFAV Yay., 2017), 1/253.

144 Şimșek, Yaratılış Olayı, 58-65.

145 Ferâhîdî, Kitâbu'l-Ayn, 839.

146 Demirci, Kur'ân Tefsirinde Farklı Yorumlar, 1/253.

147 Şimşek, Yaratılış, Olayı, 57.

148 Tâhir bin Âşûr, Tefsîru't-Tahrîr ve't-Tenvîr, 2/214-215.

149 Nehhâs, Ebû Ca'fer Ahmed bin Muhammed bin İsmail, Meâni'l-Kur'ân, thk. Yahya Murad (Kahire: Dâru'l-hâdis, 2004), 1/556.

150 Râzî, Mefâtîhu'l-ğayb, 9-10/131; Reşîd Rızâ, Tefsîru'l-Kur'âni'l-Hakîm, 5/268-269.

151 er-Rum 30/21; en-Nahl 16/72. İbrahim, Kur'an Yorumlarında Kadın, 79-80.

152 et-Tevbe 9/128; Âl-i İmrân 3/164.

153 Reşîd Rızâ, Tefsîru'l-Kur'âni'l-Hakîm, 5/268-269; Taslaman, Evrim Teorisi Felsefe ve Tanrı, 267; a. mlf. Bir Müslüman Evrimci Olabilir mi, 90. 
cinsinden, toprak ve sudan yaratıldığını söyleyebiliriz. ${ }^{154}$ Eğer Havvâ, Hz. Âdem'in kaburga kemiğinden yaratılmış olsaydı onun bir uzvu, bir parçası sayılırdı ve nasıl ki kişi kendi canından, kanından biri ile evlenemiyorsa aynı şekilde Hz. Âdem'in de Havvâ ile evlenmemesi gerekirdi. ${ }^{155}$

"Nefs-i vâhide" ifadesinde geçen "nefs" kelimesinin dişil olduğu için yaratıllşın Âdem'den değil kadından olması gerektiği ileri sürülmüş ise de 156 biz buna katılmıyoruz. Zira nefs kelimesinin müennes olması ifade ettiği kişinin de müennes olmasını gerektirmez. Ki birçok âyette nefs kelimesi erkekleri ifade etmek için kullanılmıştır. A'râf, 7/189. âyette tek nefsin eşine/zevcesine yaklaştığı ve zevcesinin hamile kaldığı bildirilmektedir. Âyetten tek nefsin erkek, zevcesinin ise dişi cinsiyete sahip olduğu anlaşılmaktadır. Bu da tek nefis ile Âdem'in, zevc ile Havvâ'nın kastedildiğini ${ }^{157}$ göstermektedir. ${ }^{158}$ Âyette tek nefsin sükûn bulması için zevcesinin kendisinden veya cinsinden yaratıldığı ifade edilirken "yeskunu" fiili eril/müzekker bir zamire isnat edilmektedir. Bu da "nefsi vâhide"nin cinsiyetinin erkek olduğunu göstermektedir.

\section{Hz. Âdem'in Cenneti}

"Cennet” kelimesi sözlükte, "örtmek, gizlenmek" anlamında olup, "bitkileri, ağaçları çok olan yer veya bahçe" manasındadır. ${ }^{159}$ Ağaç gölgeleri tarlayı kapladığı için bahçeye "cennet" denilmiştir.160 Dünya bahçeleri için de cennet kelimesi kullanılmıștır. ${ }^{161}$

Hz. Âdem'in ilk yaratıldığında yerleştirildiği ve kovulduğu cennet 162 konusunda müfessirler ikiye ayrılmışlardır.163 Müfessirlerin çoğuna göre Hz. Âdem,

154 İbnu'l-Cevzî, Zâdu'l-mesîr, 253; Reșîd Rızâ, Tefsîru'l-Kur'âni'l-Hakîm, 1/231-232; Muhammed Cemaluddîn el-Kâsımî, Mehâsinu't-te'vîl/Tefsîru'l-Kasimî, thk. Ahmed bin Alî, Hamdî Subh (Kahire: Dâru'l-Hadîs, 2003), 3/7; Gördük, "İlk İnsan Nesli Nasıl Devam Etti? Ensest İlișki İddiası Üzerine Eleștirel Bir Analiz”, 72; Deniz, Kur'an'a Göre Hz. Âdem(a.s.)'ın Serüveni, 92-94; Öztürk, Kur'an ve Yaratilıș, 162.

155 Okuyan, Kıssalar Ne Söyler Yaratılıș ve Hz. Âdem I, 81.

156 Sarmıș, Kur'ân'a Göre Insan'ın Yaratılması ve Çoğalması, 72-73; Sonia Cihangir, Kadına Dair Hürafeler ve Gerçekler (İstanbul: Ozan Yay., 2016), 10-14.

157 Mukâtil bin Süleymân bin Beşîr, Tefsiru Mukâtil bin Süleymân, thk. Ahmed Ferid (Beyrut: Dâru'lKütübi'l-İlmiyye, 2003), 1/213-328; Taberî, Câmiu'l-beyân an te'vîli âyi'l-Kur'ân, 6/178-180; Maverdî, en-Nuket ve'l-uyûn, 2: 286-287; İbnu'l-Cevzî, Zâdu'l-mesîr fî ilmi't-tefsîr, 533-534. Birinci, “"Nefs-i vâhide” İfadesinden Hareketle Kadının Yaratılışı Hakkında Bir Değerlendirme”, 157.

159 Ferâhîdî, Kitâbu'l-ayn, 130-131; Cevherî, Mu'cem es-sihâh, 192-194; Firuzâbâdî, el-Kâmusu'lmuhît, 242-243; Ragıb el-İsfehânî, el-Müfredât fí garîbi'l-Kur'ân, 105-106.

Şimşek, Yaratılıs Olayı, 75. el-Bakara 2/265; er-Ra'd 13/4; Sebe' 34/15.

Hz. Âdem'in cenneti ile ilgili tartışmalar için bk. Ebû Abdullâh Şemsuddîn Muhammed bin Ebû Bekr bin Kayyim el-Cevziyye, Hâdi'l-ervah ilâ bilâdi'l-efrâh, thk. Zâid bin Ahmed en-Neșîrî (Mekke: Dâru'l-Âlemi'l-Fevâid, 1428), 47-78; Okumuş, Eşref'ten Esfel'e Insanın Serüveni, 149-199; Ömer Kara, Tefsir Tedkikleri I (İstanbul: İFAV Yay., 2017), 78-112.

163 Maverdî, en-Nuket ve'l-uyûn, 1/104; İbnu'l-Cevzî, Zâdu'l-mesîr, 55; Râzî, Mefâtîhu'l-ğayb, 3-4/4-5; Beyzâvî, Envâru't-tenzîl,1/54; Ferruh Kahraman, "Bir Tefsîr-Kelâm Problemi: Hz. Âdem'in Yasak Ağaca Yaklaşması”, Sakarya Üniv., Illahiyat Fak. Dergisi 15/27 (2013/1), 192. 
mükâfat cennetine yerleștirilmiş ve işlediği günahla birlikte buradan kovulmuştur. ${ }^{164}$ Bir kısım müfessire göre ise Hz. Âdem yeryüzünde bir bahçeye yerleştirilmiş ve günahtan sonra buradan uzaklaştırılmıştır. ${ }^{165}$ Tevrat'ın verdiği bilgiye göre Hz. Âdem Aden'de bir bahçede yaratılmıştır. 166 Âdem'in cennetinin mükâfat cenneti olduğunu söyleyenler; cennet kelimesinin âyette "el" belirlilik takısı ile geldiğini bunun da mükâfat cennetine işaret ettiğini,167 Hz. Musa'nın cennetten çıkmalarına sebebiyet verdiği için Hz. Âdem'e suçlamada bulunduğunu, ${ }^{168}$ cennetten yeryüzüne inmelerinin "hubut" kelimesi ile ifade edildiğini, ${ }^{169} \mathrm{~Hz}$. Peygamberin mi'raçta cenneti müşahede ettiğini delil olarak ileri sürmüşlerdir. ${ }^{170}$

Hz. Âdem'in yeryüzünde bir bahçede yaratıldı̆̆ını ve oradan sürüldüğünü ifade edenler; mükâfat cennetinin var olup olmadığının tartışmalı olduğunu, ${ }^{171}$ mükâfat cennetine girenlerin bir daha oradan çıkmayacaklarının, orada imtihanın olmayacağının ve orada herhangi bir kısıtlamanın bulunmadığının âyetlerde belirtildiğini, ${ }^{172}$ Hz. Âdem'in yeryüzünde halife kılınmasının yeryüzünde yaratılmasını gerektirdiğini, ${ }^{173} \mathrm{~Hz}$. Âdem'in yerde yaratılıp gökyüzüne çıkarıldığına dair herhangi bir delilin bulunmadığını, şeytanın ve vesvesesinin cennete giremeyeceğini, cennette günah işlemenin mümkün olmadığını, ${ }^{174}$ "inin" anlamına gelen "هبطوا" kelimesinin "hayat düzeyinin düşmesine" işaret ettiğini, "hubut" kelimesinin Kur'ân'da gemiden inmek, ${ }^{175}$ şehre inmek/girmek ${ }^{176}$ anlamlarında da kullanıldığını, âyette cennetin genişliğinin gökler ve yer kadar olduğunun belirtildiğini bu durumda mükâfat cennetinin gökte olamayacağını, ${ }^{177}$ ebedi olan

\footnotetext{
164 Taberî, Câmiu'l-beyân an te'vîli âyi'l-Kur'ân,1/303-315; Beyzâvî, Envâru't-tenzîl,1/54; Nesefi, Medâriku't-tenzîl, 46; İmâduddîn Ebû'l-Fidâ İsmail bin Ömer bin Kesîr el-Kureșî, Tefsîru'lKur'âni'l-Azîm, 4 Cilt (Kahire: Dâru'l-Hadîs, 7. Basım, 1993), 1/119-121; Kurtubî, el-Câmi' lî ahkâmi'l-Kur'ân, 1/280-283; Tâhir bin Âșûr, Tefsîru't-Tahrîr ve't-Tenvîr, 1/430-431; Şimșek, Yaratılış Olayı, 75-81; Okuyan, Kıssalar Ne Söyler Yaratılış ve Hz. Âdem I, 143; Kahraman, Bir Tefsîr-Kelâm Problemi: Hz. Âdem'in Yasak Ağaca Yaklaşması, 191-224.

165 Tabbara, Kur'an'da Peygamberler ve Peygamberimiz, 43-44; Okuyan, Kıssalar Ne Söyler Yaratıllş ve Hz. Âdem I, 143; Sarmıș, Kur'ân'a Göre İnsan'ın Yaratılması ve Çoğalması, 238-248; Okumuş, Eşref'ten Esfel'e İnsanın Serüveni, 153; Erdem, Hazreti Âdem (İlk İnsan), 150-154; Atay, "Allah'ın Halifesi: İnsan”, 79; İkbal, İslamda Dini Tefekkürün Yeniden Teșekkülü, 112; Hasan Elik \& Muhammed Coşkun, Tevhit Mesajı Özlü Kur'an Tefsiri (İstanbul: Fikir Yay., 2013), 18; İslamoğlu, Kur'an ve Tabiat Ayetleri Ișı̆ı̆ında Yaratılıș ve Evrim, 230.

166 Tekvîn, 2/8-9.

167 el-Bakara 2/35. Nesefi, Medâriku't-tenzîl, 46.

168 Buhârî, "Kader", 11; "Enbiyâ", 31; "Tevhîd", 37; Müslim, "Kader", 13; Ebu Davûd, "Sünnet”, 17; Tirmizî, "Kader", 2.

169 el-Bakara $2 / 36$.

170 İbn Kayyim el-Cevziyye, Hâdi'l-ervah ilâ bilâdi'l-efrâh, 47-78; Nesefi, Medâriku't-tenzîl, 46; Şimşek, Yaratılış Olayl, 75-81; Kahraman, "Bir Tefsîr-Kelâm Problemi: Hz. Âdem'in Yasak Ağaca Yaklaşması”, 191-224; Deniz, “Kur'an'a Göre Hz. Âdem (a.s.)'ın Serüveni”, 95.

171 İbn Kayyim el-Cevziyye, Hâdi'l-ervah ilâ bilâdi'l-efrâh, 24-46.

172 Hûd 11/108; el-Hicr 15/48.

173 el-Bakara 2/30.

174 et-Tûr 52/23; en-Nebe' 78/ 35; el-Vâkı 56/25-26.

175 Hûd $11 / 48$.

176 el-Bakara 2/61.

177 Âl-i İmrân 3/133.
} 
mükâfat cennetinde şeytanın "huld ağacı" ile saptırmasının" ${ }^{178}$ anlamsız olduğunu delil olarak ileri sürmüşlerdir. ${ }^{179}$

Hz. Âdem'in cennetinin nerede olduğu konusunda sükûtu tercih edenler; mevzunun gaybi bir mesele olduğunu, Kur'ân ve sünnette mevzu ile ilgili net bir bilginin bulunmadığını, ileri sürülen delillerin yetersiz ve çelişkili olduğunu, bu tür teferruatlarla uğraşmanın Kur'ân üslubuna aykırılık arz ettiğini, cennetin yerini tespit etmenin iman ve amel açısından bize pratik fayda sağlamadığını ifade etmişlerdir. ${ }^{180}$

Âdem kıssasını sembolik/temsili kabul edenler ise, kıssanın Kur'ân'daki haliyle insanın kozmik kaderine ilişkin dramatik bir kıssa olduğunu, zamansal ve mekânsal açıdan herhangi bir duruma karşılık gelmediğini, bundan dolayı kıssada yer alan "cennet" kelimesinin gerçek bir mekân olarak anlaşılmayacağını ve özellikle varlık ötesi alanla irtibatlandırılmaması gerektiğini181 cennetten kovulmayı ifade eden "hubut" ifadesinin insanın saf ve sade şuurdan şuuru zatın ilk kıvılcımına intikali182 ve manevi düşüşü anlattığını, ${ }^{183} \mathrm{~Hz}$. Âdem'in yaratılış sürecinin soyut değerler üzerinden anlaşılması gerektiğini1 ${ }^{184}$ ifade etmişlerdir.

\section{Hz. Âdem'e Yasaklanan Ağaç}

Hz. Âdem'e yasaklanan ağaçla ilgili tefsirlerde çokça malumat bulunmaktadır.185 Yahudilere göre, yasaklanan ağaç "iyilik ve kötülüğü bilme ağacı" iken, ${ }^{186}$ Hristiyanlara göre ise yasaklanan ağaç "cinsellik"tir. ${ }^{187}$ Hıristiyanlara göre Âdem'in yasak meyveden yiyerek yüklendiği günah, bütün insanoğluna geçmiş, $\mathrm{Hz}$. İsa da kanını akıtmak suretiyle insanlığı bu ağır vebalden kurtarmıştır. ${ }^{188} \mathrm{Bu}$ asli günah anlayışı ise Kur'ân'ın, "kimse kimsenin günahını yüklenmez"189 ilkesine terstir. Hıristiyanların inancının tam aksine Allah, Hz. Âdem ve Havvâ'nın; "Rabbimiz! Kendimize zulmettik, bizi affetmez bize acımazsan ziyana uğrayanlardan oluruz"190

178 Tâhâ 20/120.

179 İbn Kayyim el-Cevziyye, Hâdi'l-ervah ilâ bilâdi'l-efrâh, 47-78; Şimşek, Yaratılış Olayı, 75-81; M. Sait Şimşek, Hayat Kaynağı Kur'an Tefsiri (İstanbul: Beyan Yay., 2012), 1/65-71; Reşîd Rızâ, Tefsîru'l-Kur'âni'l-Hakîm, 1/228-230; Kahraman, “Bir Tefsîr-Kelâm Problemi: Hz. Âdem'in Yasak Ağaca Yaklaşması”, 191-224; Okumuş, Eşreften Esfel'e Insanın Serüveni, 181-183; Deniz, "Kur'an'a Göre Hz. Âdem (a.s.)'ın Serüveni”, 92-94; Bolay, “Âdem”, 359; Dartma, "Hz. Âdem'in Dışlandığı Cennetin Dünyası Meselesi”, 11-21; Ateș, "Kur'an-ı Kerim’e Göre Evrim Teorisi”, 141; Okuyan, Mehmet, Kıssalar Ne Söyler Hz. Nuh II (İstanbul: Düşün Yay., 2018), 207; Taslaman, Bir Müslüman Evrimci Olabilir mi, 98-102; Yakıt, Kur'ân'ı Anlamak, 77-80, Demirci, Kur'ân Tefsirinde Farklı Yorumlar, 1/63.

180 Mâturîdî, Tevilâtü Ehli's-Sünne, 1/425; Kara, Tefsir Tedkikleri I, 111-112.

181 Öztürk, KIssaların Dili, 160-161.

182 İkbal, İslamda Dini Tefekkürün Yeniden Teșekkülü, 102.

183 Elik \& Coșkun, Tevhit Mesajı Özlü Kur'an Tefsiri, 19.

184 Okumuş, Eşref'ten Esfel'e Insanın Serüveni, 154.

185 Ağaç cinsi için bk. Aydemir, Tefsirde İsrâiliyyât, 315-316.

186 Tekvîn, 2/1-17.

187 Şimşek, Yaratılış Olayı, 83-87.

188 Cerrahoğlu, Kur'an'da İnsanın Yaratılış Sahnesinin Düşündürdükleri, 94.

189 Fâtır 35/18.

190 el-A'raf 7/23. 
şeklindeki tövbelerini kabul etmiştir.191 Tevrat'ın yasak ağacı "iyilik ve kötülüğü bilmek" olarak ifade etmesi de Kur'ân'a terstir. Zira bilmeyen biri sorumlu değildir 192 ve kişi bilmediği bir yasağı çiğnediği için ceza almaz. ${ }^{193}$ Kaldı ki Allah bu yasağın öncesinde Âdem'e isimleri öğreterek ${ }^{194}$ bilmesini dilemiştir. Emir ve yasak uyuyan zihne değil diri zihne yapılır, tabiri caizse bilmemek zihnin uyuması demektir.

Müfessirlerin genel kanaati yasaklanan ağacın "elma, incir, buğday vs." olduğu yönündedir. ${ }^{195}$ Bazı müfessirlere göre yasak ağaç neslin çoğalmasına vesile olan "cinsel birleşmeyi" anlatan mecazi bir ifadedir. ${ }^{196}$ Zira Kur'ân'da kadın erkek ilişkisi mecazi anlatımlarla ifade edilmekte, kadın tarlaya ${ }^{197}$ benzetilmektedir. Âdem ve Havvâ'nın yasak ağaçtan yer yemez avret yerlerinin kendilerine görünmesi, ${ }^{198}$ İblis'in Âdem'i kandırmak için "huld ağacı"199 tabirini kullanması ve İslâm kültüründe insanın neslinin, sülalesinin ifadesi bağlamında "soy ağacı" veya "şecere" tabirinin kullanılması bu görüşü destekleyen delillerden bazılarıdır. ${ }^{200}$

Bazı müfessir ve araştırmacılar, Kur'ân'ın ağacın cinsini belirtmediğini dolayısıyla bu konuda konuşmanın gereksizliğini ifade ederken ${ }^{201}$ kimi araştırmacılar tarafından ise ağacın sembolik bir ifade olduğu, yasaklanan şeyleri simgelediği, cennetin "nimeti”, ağacın "kötülüğü" simgelediği, ${ }^{202}$ Kur'ân'ın Âdem kıssasındaki yılan ve kaburga kısmını hazfettiği, yılanın Sümerlerde erkeği, elmanın bekâreti sembolize ettiği ifade edilmiştir. ${ }^{203}$

Kanaatimizce Hz. Âdem'e yasaklanan meyve cinsel ilişkidir. “Şeytan, Âdem ve Havvâ'nın avret yerlerini birbirlerine göstermek için onlara fisıldayıp akıllarını bulandırdı ve 'sirfmelek olursunuz ya da sonsuz yaşayanlardan olursunuz diye Rabbiniz size bu ağacı yasakladı' dedi”"204 ve "Ey Âdemoğulları! Şeytan, anne babanızın (Âdem ve

191 el-Bakara 2/37; Tâhâ 20/122.

192 Şimşek, Yaratılış Olayı, 50-51.

193 en-Nisâ 4/17; ez-Zümer 39/9.

194 el-Bakara 2/31.

195 Taberî, Câmiu'l-beyân an te'vîli âyi'l-Kur'ân, 1/303-308; Mukâtil bin Süleymân, Tefsiru Mukâtil bin Süleymân, 1/42-43; Maverdî, en-Nuket ve'l-ûyûn, 1/105; İbnu'l-Cevzî, Zâdu'l-mesîr, 55; Râzî, Mefâtîhu'l-ğayb, 3-4/4-5; Nesefi, Medâriku't-tenzîl, 47; İbn Kesîr, Tefsîru'l-Kur'âni'l-Azîm, 1/117118. Tâhir bin Âșûr, Tefsîru't-Tahrîr ve't-Tenvîr, 1/432.

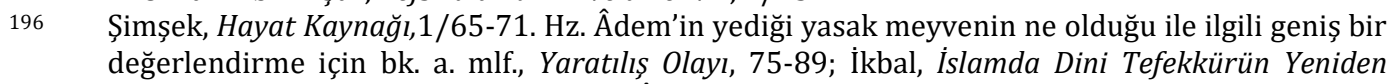
Teşekkülü, 99; Deniz, “Kur'an'a Göre Hz. Âdem (a.s.)'ın Serüveni”, 96; Ateș, "Kur'an-ı Kerim'e Göre Evrim Teorisi", 142-143; Yakıt, Kur'ân'ı Anlamak, 81; İslamoğlu, Kur'an ve Tabiat Ayetleri Işığında Yaratılış ve Evrim, 233-236; Demirci, Kur'ân Tefsirinde Farklı Yorumlar, 1/64.

197 el-Bakara $2 / 223$.

198 el-A'râf 7/20-22.

199 Tâhâ 20/121.

200 Şimșek, Hayat Kaynağı,1/65-71; Kahraman, Bir Tefsîr-Kelâm Problemi: Hz. Âdem'in Yasak Ağaca Yaklaşması, 201.

201 Mâturîdî, Tevilâtü Ehli's-Sünne, 1/426; Taberî, Câmiu'l-beyân an te'vîli âyi'l-Kur'ân, 1/303-308; Kurtubî, el-Câmi' lî ahkâmi'l-Kur'ân, 1/283-285; İbn Kesîr, Tefsîru'l-Kur'âni'l-Azîm, 1/118; Erdem, Hazreti Âdem (İlk Insan), 158.

202 Reşîd Rızâ, Tefsîru'l-Kur'âni'l-Hakîm, 1/233-235; Elik \& Coşkun, Tevhit Mesajı Özlü Kur'an Tefsiri, 19.

203 İkbal, İslamda Dini Tefekkürün Yeniden Teșekkülü, 99-100.

204 el-A'râf 7/20. 
Havvâ'nın) avret yerlerini kendilerine göstermek için libaslarını soymak suretiyle onları cennetten çıkarttığı gibi sizi de yanıltmasın"205 âyetlerinde geçen "avret yerlerinin gösterilmesi, elbiselerinin soyulması" ifadelerinde açıcça cinsel ilişkiye vurgu yapılmaktadır. Âdem'in cinsel ilişki yasağını çiğnemesi zina olarak algılanmamalıdır. Zira âyette geçen haramın tahrimi mi, tenzihi mi olduğu tartışmalıdır. ${ }^{206}$ Ayrıca bu süreçte Havvâ onun eşidir ve Âdem'in eşine cinsel açıdan yaklaşması yasaklanmıştır. Tıpkı hayız döneminde erkeğin eşi ile cinsel ilişkiye girmesinin yasaklanması ${ }^{207}$ gibi.

Âyette yasak ağaçtan ilk kimin yediği de söylenmemektedir. ${ }^{208}$ Tevrat'a göre Âdem'i yasak meyveden yemesi için kandıran kadın²09 iken Kur'ân her ikisinin aynı anda meyveden yediklerini ve şeytana uyduklarını ${ }^{210}$ ifade etmekte ve bu konuda Havvâ'dan daha çok Âdem'i kınamaktadır. ${ }^{211}$

\section{Hz. Âdem'e Ruh Üflenmesi}

Arapça olan ruh kelimesi, Kur'ân'da, farklı şekil ve bağlamlarda yirmi yerde, yirmi bir defa 212 kullanılmıştır. ${ }^{213}$ Kelime sözlükte, "Cebrail, vahiy, hafif esinti, nefes, öz, can, ilham ve rüzgâr” anlamlarına gelmektedir. ${ }^{214}$ Kur'ân'da ruh kavramı genelde Kur'ân, İncil, Cebrail, İsa ve vahiy anlamlarında kullanılmıştır. Farklı felsefi akım ve kültürel atmosferlerde oluşan ruh anlayışı, ${ }^{215}$ zaman zaman İslâm dünyasında da etkisini göstermiştir. Ancak bu görüşlerin bir kısmı kabul edilmiş, bir kısmı da eleştirilmiștir. ${ }^{216}$

Allah'ın yaratma planında özel bir yer tuttuğunu göstermek üzere Allah'ın, Âdem'e ruhundan üflediğini söylediği, ${ }^{217}$ Allah'ın kendisinden üflediği ruhtan dolayı insanın tanrı ile akraba haline geldiği, insanın "içinde tanrı bulunan küçük bir tabiat" olduğu,218 ruh üflemenin Âdem'i canlı yapacak şeyin onda var edilerek onun zu hayat/yaşam sahibi, nefes alıp verebilen bir varlık haline getirilmesinden kinaye olarak söylendiği, Allah hakkında insanlardaki gibi bilfiil üflemeyi düşünmenin

\footnotetext{
205 el-A'râf 7/27.

Râzî, Mefâtîhu'l-ğayb, 3-4/5.

el-Bakara 2/222.

Şimșek, Hayat Kaynă̆ı, 1/65-71.

Tekvîn, 3/1-14.

Tâhâ 20/121.

Füruzan Rasıkhî, “Kur’an'ın ve Kutsal Kitabın Kadına Bakıș Açılarının Karşılaștırılması (Yaratılış Hikâyesine Göre)", Misbah Dergisi, 1/3-4 (2013), 157.

el-Bakara 2/87, 253; en-Nisâ 4/171; el-Mâide 5/110; el-Hicr 15/29; en-Nahl 16/2, 102; el-İsrâ 17/85; Meryem 19/17; el-Enbiyâ 21/91; eș-Șuarâ 26/193; es-Secde 32/9; Sâd 38/72; el-Gâfir 40/15; eş-Şûrâ 42/52; el-Mücâdele 58/22; et-Tahrîm 66/12; el-Meâric 70/4; en-Nebe' 78/38; elKadr 98/4.

213 Muhammed Fuâd Abdulbâkî, el-Mu'cemu'l-müfehres li elfâzı'l-Kur'âni'l-Kerîm, 400.

214 Ferâhîdî, Kitâbu'l-ayn, 230-231; Cevherî, Mu'cem es-sıhâh, 434-435; Firuzâbâdî, el-Kâmusu'lmuhît, 539-541; Ragib el-İsfehânî, el-Müfredât fí garîbi'l-Kur'ân, 210-213.

215 Ruh hakkında bk. Merdin, İslamın Pavlusları II, 210-232; Şimşek, Yaratılış Olayı, 37-45.

216 Şaban Karasakal, "Kur'an'da Ruh Kavramı", The Journal of Academic Social Science Studies 28/2 (2014), 288-289.

217 Düzgün, Sarp Yokuşun Eteğinde İnsan, 25.

218 Șeriati, Cöle Iniș (Hubut-Kevir), 117, 134.
} 
mümkün olmadığı, ${ }^{219} \mathrm{~Hz}$. Adem'e ruhun üflenmesi ile ilgili tüm açıklamaların meçhulü taşlamak anlamına geldiği ve ruh üflemenin mecazi bir anlatım olduğu ${ }^{220}$ ifade edilmiştir.

Âyetlerde geçen "min ruhi" ifadesindeki221 ruhum ifadesi ile kalemim misalinde olduğu gibi Allah'ın maliki olduğu ruhun kastedildiği, "başım” denildiğinde başın bizim bir parçamız olduğunun anlaşıldığı ama "kalemim" denildiğinde kalemin bizim bir parçamız değil, sahip olduğumuz bir nesne olduğunun anlaşılacağı, isim tamlamasının mülkiyet ifade etmek için kullanılabileceği gibi ba'ziyet/kısım ifade etmek için de kullanılabileceği, dolayısı ile ruhun Allah'ın bir parçası olmadığı,222 "min" edatının bu âyetlerde ba'ziyet değil mülkiyet ifade ettiği, 223 "min ruhi" ifadesinin Hz. Âdem'i şereflendirmek ve onun değerini yüceltmek için söylendiği, ${ }^{224}$ ruhun Allah'tan bir parça olmadığı değilse Âdem'in ruhunun tanrısal ruh hüviyetini kazanacağı ${ }^{225}$ ifade edilmiştir. Kanaatimiz Hz. Âdem'e yapılan ruh üflemenin bildiğimiz manada bir üfleme olmadığı, ruhun Allah'tan bir parçayı ifade etmediği ve ruh üflemenin Âdem'in iradeli kılınmasıyla ilgili olduğu ${ }^{226}$ yönündedir.

\section{Hz. Âdem'in Halifeliği}

"Arka" anlamına gelen "half" sözcüğünden türeyen halife kavramı sözlükte sonradan gelen, kendinden öncekilerin yerine geçen anlamına gelmektedir. ${ }^{227}$ Halife kelimesi, ismi fail ve ismi mef'ul olarak kullanılabilen bir formdur. İsmi fail olarak kullanıldığında "yerine geçtiği kimsenin işini üzerine alan, yürüten”, ismi mef'ul olarak kullanıldığında ise "yerine başkası geçen" anlamındadır. ${ }^{228} \mathrm{~Hz}$. Âdem'in kime halife olduğu ve halifelik mevzusu tartışmalı konulardan biridir. "Yeryüzünde bir halife kılacağım" âyetine 229 dayanılarak insanın Allah'ın halifesi ve yeryüzünde Allâh adına ilahi kural ve kanunları uygulama yetkisine sahip Allah'ın temsilcisi olduğu ifade edilmiş̧230 ise de bu düşüncenin doğru olmadığı, Allah'ın halife ifadesini âyette

\footnotetext{
219 İbnu'l-Cevzî, Zâdu'l-mesîr, 761; Hüseyin Çelik, “Kur'an'a Göre Hz. Âdem'in Yaratılıșı”, İstanbul Üniv., İlahiyat Fak. Dergisi 2/2 (2011), 62-65; Merdin, İslamın Pavlusları II, 213.

220 Sarmış, Kur'ân'a Göre İnsan'ın Yaratılması ve Çoğalması, 170-172; Merdin, İslamın Pavlusları II, 213.

221 es-Secde 32/9; el-Hicr 15/29; Sâd 38/72.

222 Şimșek, Hayat Kaynağı, 3/122; a.mlf. Yaratılış Olayı, 39; Çelik, "Kur'an'a Göre Hz. Âdem'in Yaratılışı", 62-64; Yakıt, Kur'ân'ı Anlamak, 94.

223 Sarmıș, Kur'ân'a Göre İnsan'ın Yaratılması ve Çoğalması, 141-178.

224 İbnu'l-Cevzî, Zâdu'l-mesîr, 761.

225 Demirci, Kur'an'ın Ana Konuları, 91; Çelik, Kur'an'a Göre Hz. Âdem'in Yaratılışı, 62- 65.

226 Ragıb el-İsfehânî, el-Müfredât fí garîbi'l-Kur'ân, 15.

227 Ferâhîdî, Kitâbu'l-ayn, 220-221; İbn Fâris, Mekâyîsu'l-luğâ, 267-268; Cevherî, Mu'cem es-sihâh, 312-314; Ragıb el-İsfehânî, el-Müfredât fî garîbi'l-Kur'ân, 162-163; Taberî, Câmiu'l-beyân an te'vîli âyi'l-Kur'ân, 1/262.

228 Kurtubî, el-Câmi' lî ahkâmi'l-Kur'ân, 1/260; Şimșek, Yaratılış Olayı, 23.

229 el-Bakara 2/30.

230 Taberî, Câmiu'l-beyân an te'vîli âyi'l-Kur'ân, 1/263; Maverdî, en-Nuket ve'l-uyûn, 1/95-96; Râzî, Mefâtîhu'l-ğayb, 1-2/152; Beyzâvî, Envâru't-tenzîl, 1/49; Nesefi, Medâriku't-tenzîl, 232; Kurtubî, el-Câmi' lî ahkâmi'l-Kur'ân, 1/260; İkbal, İslamda Dini Tefekkürün Yeniden Teșekkülü, 112; Erdem, Hazreti Âdem (İlk Insan), 127; Atay, “Allâh'ın Halifesi: İnsan”, 71-80; İbrahim Görener, “Âdemin Cennetten Yeryüzüne İnişi”, Bilimname Dergisi 18 (2010/1), 61
} 
nekre/belirsiz olarak kullandığı, kendisine nispet etmediği, halife kelimesinin "yerine geçilen kimsenin yokluğunda" kullanıldığı oysaki Allah'ın yok olması ve insanın O'nun yerini alması gibi bir durumun söz konusu olamayacağı, Hz. Ebu Bekir ve Hz. Ömer'in kendilerine "Allah'ın halifesi" değil "Rasulullah'ın halifesi" denilmesini istedikleri ifade edilmiş ve bu düşünceye karşı çıkılmıştır.231

Halife olacak kişinin "kan dökücü ve fesat ehli" olacağını ileri süren meleklerin, Hz. Âdem'i değil kendisinden sonrakileri kastettiklerini düşünmekteyiz.232 Zira âyette "halife" kelimesi nekre olarak gelmektedir. Kur'ân'da, insanlardan önce cinlerin yaratıldığının ifade edilmesi ${ }^{233}$ insanların cinlerin yerine geçerek onlara halef oldukları görüşünün ortaya atılmasına neden olmuştur. ${ }^{234}$ Âdem'in insana benzeyen ve nesli tükenen başka bir varlığın yerine geçmiş olabileceği de ifade edilmiştir. ${ }^{235} \mathrm{~Hz}$. Âdem'in ilk insan olmadığına, onunla birlikte birçok insanın yaratıldığına inananlar ise âyette geçen halife ile bir insanın değil insan ırkının kast edildiğini söylerler. ${ }^{236}$ Kanaatimizce Bakara, 2/30. âyette kullanılan "halife" kavramı sonradan kazandığı siyasi anlamda değil, lugavi anlamda "birinin yerini almak" anlamında kullanılmıştır ve insan için "Allah'ın halifesi” tabirini kullanmak doğru değildir. Âdem bağlamında halife tabirinin kullanılması Hz. Âdem'in devamının geleceği, varlığının kendisi ile sınırlı kalmayacağı, neslinin de olacağı, insan neslinin birbirini takip edeceği anlamına gelmektedir.

Meleklerin insanın kan dökücülüğünü ve ifsadını nereden bildikleri konusu da İslâm ilim tarihinde tartışma mevzusudur. İbn Abbas ve İbn Mesud'a göre bu bilgi Allah tarafından meleklere verilmiştir. ${ }^{237}$ Meleklerin, Allah'tan aldıkları bilgiyle, Levhi Mahfuz'a vakıf olarak, kendileri dışındakilerin günah işleyen tabiatta yaratılmalarından yola çıkarak ya da rivâyetlerde geçtiği gibi Âdem öncesindeki varlıkların eylemlerine bakarak bu bilgileri elde ettikleri ifade edilmiştir. ${ }^{238}$ Meleklerin insandan önce insana benzeyen varlıkları görüp bu karara vardıkları ifade edilmişs239 ise de Aydemir, bu bilginin mesnetsiz olduğunu ifade etmiştir. ${ }^{240}$ İnsan

231 Şimşek, Hayat Kaynağı, 1/55-58; a. mlf., Yaratılış Olayı, 23-28; Abdurrahmân Hasan Habenneke el-Meydânî, Le yasihhu en yukale el-insânu halifetun anillahi fí arzihi (Beyrut: Mektebetü İhyâi Turâsi'l- İslâmî, 1991), 5-65; Muammer Esen, "İnsanın Halifeliği Meselesi", Ankara Üniv. İlahiyat Fak. Dergisi, 45 (2004), 15-37.

232 İbn Kesîr, Tefsîru'l-Kur'âni'l-Azîm, 1/104-105.

233 el-Hicr 15/27.

234 Maverdî, en-Nuket ve'l-uyûn, 1/102; Şimșek, Yaratılış Olayı, 23; Dartma, Kur'an Bağlamında İlk İnsan ve Nübüvvet-Fıtrat İlişkisi, 14; Said Nursi, İşaratü'l-İ'caz, çev. Abdulmecid Nursi (İstanbul: Sözler Yayinevi, 2004), 174-175.

235 Reșîd Rızâ, Tefsîru'l-Kur'âni'l-Hakîm, 1/214-215; Şimşek, Yaratılış Olayı, 24-27.

236 Sarmış, Kur'ân'a Göre İnsan'ın Yaratılması ve Çoğalması, 56.

237 Taberî, Câmiu'l-beyân an te'vîli âyi'l-Kur'ân, 1/267-274; İbnu'l-Cevzî, Zâdu'l-mesîr, 53; Râzî, Mefâtîhu'l-ğayb, 1-2/153; Beyzâvî, Envâru't-tenzîl, 1/50; İbn Kesîr, Tefsîru'l-Kur'âni'l-Azîm, 1/104-105; Demirci, Kur'ân Tefsirinde Farklı Yorumlar, 1/57.

238 Maverdî, en-Nuket ve'l-uyûn, 1/96-97; İbnu'l-Cevzî, Zâdu'l-mesîr, 53; Râzî, Mefâtîhu'l-ğayb, 12/156; Beyzâvî, Envâru't-tenzîl, 1/50; Atay, Allah'ın Halifesi: İnsan, 75; Demirci, Kur'an'ın Ana Konuları, 86-87; Karauğuz, Âdem'in Çocukları Çiviyazılı Kaynaklar, Tevrat, Inciller ve Kur'ân'a Göre, 60-61; Bayraklı, Yeni Bir Anlayıșın Ișığında Kur'an Tefsîri, 1/301.

239 Taslaman, Bir Müslüman Evrimci Olabilir mi, 94.

240 Aydemir, Tefsirde İsrâiliyyât, 135-137. 
zaten yaratılmış ve kan döken bir varlık olduğu için âyette şimdiki zamanı da ifade eden "yufsidu" ve "yesfiku" fiillerinin kullanıldığı ve meleklerin şahit oldukları olayları dile getirdikleri fikri de ileri sürülmüştür.241

Kanaatimizce Allah, meleklere bu bilgiyi nereden aldıkları ve nasıl böyle bir fikre kapıldıklarını sormadığına göre bu bilginin kesin yollarla elde edilmiş olması kuvvetle muhtemeldir. Ayrıca meleklerin "bize öğrettiğinden başkasını bilmeyiz"242 sözleri meleklerin fikir yürütmediklerini, Âdem öncesinde gerçekleşen eylemler üzerinden konuşmadıklarını, vehbî bilgi ile hareket ettiklerini göstermektedir. Melekler aslında söz konusu halife hakkında sahip oldukları kesin bilgiye rağmen Allah'ın neden böyle bir karar verdiğini merak ettiklerinden sual etmişlerdi. Allah ise meleklerin eksik bilgi ile hareket ettiklerini, bilmedikleri başka gerçeklerin de olduğunu ifade etmiş ve Âdem'e öğrettiği isimler üzerinden meleklerin merakını gidermişti. ${ }^{243}$

\section{Meleklerin Secdesi}

Arapça " $s-c$ - $d$ " kökünden türeyen ve cahiliye döneminde "eğilmek" anlamı ile bilinen "secde" kelimesi,244 "ibadet kastıyla eğilme, alnı yere koyma, saygı gösterme, boyun eğme, başı öne eğme" gibi anlamlara gelmektedir. ${ }^{245}$ Melekler, yeryüzünde birinin halife kılınacağını duyduklarında Allah'a "kendilerinin tesbih ve takdis edip durdukları halde neden kan dökecek ve yeryüzünü fesada verecek biri/lerinin yeryüzüne yerleştirileceklerini, yere hâkim kılınacaklarını" sual ederler. ${ }^{246}$ Kimine göre bu sual bir itiraz, kimi göre ise niza/çekişmedir.247 Kanaatimizce burada melekler işin hikmetini merak etmektedirler, sualde itiraz veya nizâ söz konusu değildir. Kur'ân'da âyetlerde belirtildiği kadar ${ }^{248}$ ile melekler secde ile mükellef tutulmuş ancak kibirlendiği, kendini üstün gördüğü ve Âdem'i hor gördüğü için şeytan secde etmekten kaçınmıştır. ${ }^{249}$

Meleklerin secde ile mükellef olmalarından yola çıkılarak meleklerin irade sahibi oldukları da ileri sürülmüştür. ${ }^{250}$ Biz de meleklerin irade sahibi olduklarını

\footnotetext{
241 Okuyan, Kıssalar Ne Söyler Yaratılış ve Hz. Âdem I, 91; Yakıt, Kur'ân'ı Anlamak, 70; İslamoğlu, Kur'an ve Tabiat Ayetleri Işığında Yaratılış ve Evrim, 196-197.

el-Bakara 2/31.

el-Bakara 2/30-33.

Ebû'l-Huseyn Ahmed bin Fâris er-Razî el-Luğavî, es-Sâhibiyyu fî fikhi'l-lûğâti'l-Arabiyyeti ve mesâilihê ve süneni'l-Arab fì kelâmihê, thk. Dr. Ömer Farûk Tabbâ' (Beyrut: Dâru Mektebetü'lMeârif, 2013), 79-81.

245 Ferâhîdî, Kitâbu'l-ayn, 351; Cevherî, Mu'cem es-sıhâh, 476-477; Firuzâbâdî, el-Kâmusu'l- muhît, 594; Ragıb el-İsfehânî, el-Müfredât fí garîbi'l-Kur'ân, 229-230; İbnu'l-Cevzî, Zâdu'l-mesîr, 54. el-Bakara 2/30.

247 Maverdî, en-Nuket ve'l-uyûn, 1/93-96; İbnu'l-Cevzî, Zâdu'l-mesîr, 53; Nesefi, Medâriku't-tenzîl, 44; Muhyiddin Ebû Abdillah Muhammed b. Ali el-Arabî, Fusûsu'l-Hikem, çev. M. Nuri Gençosman (İstanbul: Kırkambar Yay., 2003), 30. el-Bakara 2/34; el-A'râf 7/11; el-Hicr 15/28-33; el-İsrâ 17/61; el-Kehf 18/50; Tâhâ 20/116; Sâd 38/71-74.

249 Hasan Keskin, “Kur'an'da Meleklerin Hz. Âdem'e Secdesinin Yorumu”, Cumhuriyet Üniv., İlahiyat Fak. Dergisi 6/2 (2002), 107.

250 Şimșek, Yaratılıș Olayı, 50-51.
} 
düşünmekteyiz, zira sual bir iradeye, değerlendirme yetisine işaret etmektedir. Secde emrinin nerede ve kaç kere tekrar ettiği tartışma konusudur. Kimi araştırmacılar tarafından meleklerin Hz. Âdem'e ilk olarak ruh üflenince, son olarak da halife tayin edilince iki defa secde ettikleri ifade ediliyor ${ }^{251}$ ise de secde emrinin bir defa verildiğini ve bu secdenin "Âdem cennette iken" gerçekleştiğini düşünmekteyiz. ${ }^{252}$ Meleklerin secdesinin nasıl olduğu konusu da tartışmalıdır. ${ }^{253}$

Meleklerin secdesinin Âdem'e değil Allah'a yapıldı̆̆̆ ${ }^{254}$ söz konusu secdenin selamla ve eğilerek saygı göstermek şeklinde olduğu, ${ }^{255} \mathrm{~Hz}$. Yusuf un kardeşlerinin secdesine benzer bir secde yapıldığı, burada Âdem'in Kâ'be gibi algllanması gerektiği, ${ }^{256}$ secde ile insanoğlunun emrine tüm varlıkların verildiğinin anlatıldığ ${ }^{257}$ ve secdenin Âdem'in şahsı ile münhasır kalmayıp, insan türünü de kapsamış olabileceği258 ifade edilmiştir. Kanaatimizce burada meleklerin secdesi bilinen manada bir secde, eğilme değil ona saygı göstermek, varlığını tanımak ona karşı görevlerini yerine getirmek anlamına gelmektedir. Zaten Kur'ân'da bahsedilen cansız varlıkların; güneş, ay, yıldız, dağ ve ağaçların secdesi259 de "emre itaat etme, verilen görevi yerine getirme" anlamında kullanılmıştır. 260

Mevdûdî (öl. 1979), söz konusu secdeyi, dünyayı ve tüm kâinatın dünya ile ilgili kısmını idare eden meleklerin, insana baş eğip, itaat etmesinin temsili bir ifadesi olarak yorumlamıștır. ${ }^{261}$ Kimileri tarafından secde emri farklı okunmuş ve Âdem'e secde eden meleklerin, iradesini yönetme yeteneğini ve akıl gücünü elde eden insana boyun eğen, hizmetine amade olan tabiat kuvvetleri olduklarını, insanın akıl gücünü elde edince tabiat kuvvetlerini emri altına aldığını, onlardan faydalanmayı öğrendiğini, onların olumsuz etkilerinin önüne geçmeyi bildiğini iddia etmişlerdir. ${ }^{262}$

252 Şimşek, Yaratılıș Olayı, 50-51.

253 İbnu'l-Cevzî, Zâdu'l-mesîr, 54.

254 Taberî, Câmiu'l-beyân an te'vîli âyi'l-Kur'ân,1/301; Râzî, Mefâtîhu'l-ğayb, 1-2/254; Beyzâvî, Envâru't-tenzîl, 1/52; Okuyan, Kıssalar Ne Söyler Yaratılış ve Hz. Âdem I, 116-118.

255 Maverdî, en-Nuket ve'l-uyûn, 1/102; Nesefi, Medâriku't-tenzîl, 44; Mâturîdî, Tevilâtü Ehli's-Sünne, 1/419; İbn Kesîr, Tefsîru'l-Kur'âni'l-Azîm, 1/115-116; Tabbara, Kur'an'da Peygamberler ve Peygamberimiz, 39; Keskin, “Kur'an'da Meleklerin Hz. Âdem'e Secdesinin Yorumu”, 119-122; Demirci, Kur'ân Tefsirinde Farkll Yorumlar, 1/59. Maverdî, en-Nuket ve'l-uyûn, 1/102-103; Beyzâvî, Envâru't-tenzîl, 1/52; Zemahșerî, el-Keșşâf an hakâiki ğavâmizi't-tenzîl, 130; Yakıt, Kur'ân'ı Anlamak, 75; Erdem, Hazreti Âdem (İlk İnsan), 131135.

257 Yakıt, Kur'ân'ı Anlamak, 75.

258 Keskin, “Kur'an'da Meleklerin Hz. Âdem'e Secdesinin Yorumu”, 119.

259 el-Hac 22/18.

260 İbn Manzûr, Ebu'l-Fazl Cemâlüddîn Muhammed bin Mukerrem el-Ifrikî el-Mısrî, Lisânu'l-Arab, thk. Yusuf Bekai v.dğr., 2 Cilt (Beyrut: Müesseseti'l-A'lem li'l-Matbuât, 2005), 1/1757-1758; Ebû Hâtim er-Râzî, Ahmet bin Hamdân, Kitâbu'z-zînê, thk. Saîd el-Ğânimî, 2 Cilt (Beyrut: Menşûrâti'lCemel, 2015), 2/742-743.

261 Mevdüdi Ebu'l-Ala, Tefhimu'l-Kur'an, çev. Muhammed Han Kayani v.dğr. (İstanbul: İnsan Yay., 1996), 3/176

262 Ateș, Kur'an-ı Kerim'e Göre Evrim Teorisi, 144.
} 
Âdem'in kendisine yapılan secdeden dolayı meleklerden üstün olduğu ifade edilmekte ${ }^{263}$ ise de biz buna katılmıyoruz. Zira bu emrin neden verildiği bize bildirilmemiştir. Şeytanın kendisini Âdem'den üstün gördüğü için secdeye varmaması ilahi emri yanlış okumasından dolayıdır. Secde emrinin üstünlük sebebi sayılmasının hiçbir dayanağı bulunmamaktadır.

\section{Hz. Âdem'e Öğretilen İsimler}

Âdem'e öğretilen isimlerin ${ }^{264}$ ne olduğu konusunda bilgi birliği bulunmamaktadır. Âdem'e öğretilen isimlerin, zürriyetinin ve meleklerin isimleri olduğu, her şeyin adı oldukları, ${ }^{265}$ Âdem'e essyaya isim koyma, mefhumlar edinme kabiliyetinin verilmesi anlamına geldiği, ${ }^{266}$ bu isimlerin o sırada yaratılmış bir topluluğun isimleri oldukları zira "hum" zamiri ve "hâulâi" işaret isminin akıllı varlıklar için kullanıldığı, dolayısıyla Allah'ın Âdem'e öğrettiği isimlerin “isim verme yeteneği" değil topluluktaki fertlerin isimleri oldukları, ${ }^{267}$ "isimleri öğrenme kabiliyeti" görüşünün âyetin zahirine uymadığı, isimlerle "ilmin"268 veya "icat etme, keşif yapma, mantiki tanımlama ve kavramsal düşünme yeteneğinin verilmesinin" 269 kastedildiği ifade edilmiştir.

Âyette Âdem'e öğretilen isimlerin mahiyeti açıkça belirtilmediği için konuyla ilgili serdedilen tüm görüşler tartışmaya açıktır. Kanaatimizce âyetin bağlamına bakmak sorunu çözmemize yardımcı olacaktır. Bakara, 2/30. âyette meleklerin, "kan dökücü ve ifsad edici birini mi yeryüzüne yerleștireceksin?" suallerini Allah, "ben sizin bilmediğiniz şeyleri bilirim" diyerek cevaplamıș ve hemen akabinde Âdem'e isimleri öğretmişti. Söz konusu isimler meleklere arz edildiğinde bilememişler, Âdem ise bilmişti. Bunun sonucunda Allah, Bakara, 2/33. âyette geçen "Size demedim mi, ben göklerin ve yerin gaybını bilirim...” sözlerini buyurmuştu. Bu bağlama bakıldığında söz konusu isimler ile kan dökme ve ifsad arasında bir ilişkinin olduğu gözlemlenir. Âdem'e öğretilen bu isimlerin, meleklerdeki olumsuz insan algısını yıkmaya dönük olduğunu ve kan dökme/fesad çıkarma eylemini boşa çıkardığını söyleyebiliriz. Buna göre söz konusu isimlerin, "kan dökme ve ifsadın" zıddı ve ilacı olduklarını söyleyebiliriz ki bize göre bunlar insani erdemlerdir, güzelliklerdir. Zaten "isim" kelimesinin "s-m-v" kökünden geldiği ve sözlükte "yücelik" anlamına geldiği ifade edilmiştir.270 Ayrıca Hz. Âdem'in isimleri bildiği için meleklerden üstün olduğunu

\footnotetext{
263 İbn Kesîr, Tefsîru'l-Kur'âni'l-Azîm, 1/116; Demirci, Kur'an'ın Ana Konuları, 93; Bolay, “Âdem”, 359; Erdem, Hazreti Âdem (Illk Insan), 131-135. el-Bakara 2/31. Ferruh Kahraman, "Hz. Âdem'e Öğretilen İsimler: Kültür Olgusunun Sembolik Söylemi", Edebali İslamiyat Dergisi 4/2 (2020), 15-40. Taberî, Câmiu'l-beyân an te'vîli âyi'l-Kur'ân, 1/282-285; Maverdî, en-Nuket ve'l-uyûn, 1/99; İbnu'lCevzî, Zâdu'l-mesîr, 54; Nesefi, Medâriku't-tenzîl, 45. İkbal, İslamda Dini Tefekkürün Yeniden Teşekkülü, 30.

Sarmıș, Kur'ân'a Göre Insan'ın Yaratılması ve Çoğalması, 47-50.

Erdem, Hazreti Âdem (İlk Insan), 142-145.

Demirci, Kur'ân Tefsirinde Farklı Yorumlar, 1/58.

Ferâhîdî, Kitâbu'l-Ayn, 383; Firuzâbâdî, el-Kâmusu'l- muhît, 646; Ragıb el-İsfehânî, el-Müfredât fî garîbi'l-Kur'ân, 247; Râzî, Mefâtîhu'l-ğayb, 1-2/162.
} 
kanıtladığ $1^{271}$ bilgisi doğru değildir. Zira bu isim bilgisi kesbi değil vehbî'dir, Âdem'in çaba sarf ederek kazandığı bir bilgi değildir. Meleklerin "bize öğrettiğinden başkasını bilmeyiz" sözleri de bu isim bilgisinin vehbîliğini ifade etmektedir. Dolayısı ile kazanılmamış bilginin Âdem'i meleklerden üstün kıldığı doğru değildir.

\section{Hz. Âdem'in Çocukları (Hâbil-Kâbil) Meselesi}

Maide, 5/27-31. âyetlerde Hz. Âdem'in iki oğlundan bahsedilmektedir. ${ }^{272}$ Kur'ân'da ayrıntı bilgiye yer verilmezken âyette zikredilen iki kardeşin hikâyesi birçok israili habere konu olmuştur. ${ }^{273}$ Sümer edebiyatında da işlenen ${ }^{274}$ ve Tevrat'ın etkisindeki israili rivâyetlerde aktarıldığına göre; Âdem'in iki oğlundan katil olanın adı Kâbil'dir ve tarımla uğraşmaktadır. Diğerinin adı ise Hâbil'dir ve hayvancılıkla uğraşmaktadır. ${ }^{275}$ Aslı israiliyât olduğu halde kabul gören genel kanaate göre bu dönemde kardeş evliliği meşru olduğu için çaprazlama evlilik söz konusudur ve insanlık bu evliliklerle çoğalmıştır. Havvâ her doğumda biri kız diğeri erkek olmak üzere ikiz evlat doğurmuş ve bir batında doğan kız çocuğunu başka bir batında doğan erkek çocukla evlendirmiştir. Hâbil ve Kâbil'in doğumuna kadar durum böyle devam etmiş, Kâbil güzel olduğu için aynı batında dünyaya gelen kız kardeşi ile evlenmek istemiş ve süregelen evlilik sistemini reddetmiştir. Hâbil koç, Kâbil bir demet başak kurban sunmuş ancak Hâbil'in kurbanı kabul edilmiştir. 276

Kıssa savaş, öldürme ve fesat konularında İsrailoğulları bağlamında gelmektedir. Dolayısı ile kıssa rivâyetlerde anlatıldığı gibi insanlığın nasıl çoğaldığını değil neden çoğaldığını konu etmekte ve İsrailoğullarına geçmiş üzerinden dersler vermektedir. Tanışsın, kaynaşsın diye yaratılan insanlık, ${ }^{277}$ ilk katil Kâbil'in eliyle yara almış ve insanlığın kanlı tarihi başlamıştır.278 İsrailoğulları da birbirlerinin kanını akıtmak, Hâbil'in takvasını kuşanmamak sureti ile aynı hatayı devam ettirmiştir. Yeryüzünde dökülen bu ilk kan ile meleklerin, "kan akıtacak, yeryüzünü ifsad edecek bir halife mi kılacaksın"279 sözlerindeki kaygıları gerçekleşmişti.

Âyetin belirttiği kadarı ile Allah takvalı olduğu için Âdem'in bir oğlundan (Hâbil'den) kurbanını kabul etmiştir. Zaten başka bir âyeti kerimede de

\footnotetext{
271 İbn Kesîr, Tefsîru'l-Kur'âni'l-Azîm, 1/109, 111, 112.

272 Habil ve Kabil kıssası hakkında geniş bir değerlendirme için bk. Yunus Emre Gördük, "Klasik ve Modern Kaynaklarda İlk Cinayet Kıssası (el-Maide 5/27-31): Tefsir Metodolojisi Açısından Mukayeseli Bir İnceleme", Amasya İlahiyat Dergisi, 15 (2020): 105-142.

Aydemir, Tefsirde İsrâiliyyât, 340.

Karauğuz, Âdem'in Çocukları Çiviyazılı Kaynaklar, Tevrat, Inciller ve Kur'ân'a Göre, 79-89.

Tekvîn, 4/1-16; 4/2.

Salâh Abdûlfettâh el-Hâlidî, Kur'an Öyküleri, çev: Ahmet Sarıkaya (Konya: Kitap Dünyası, 2002),

5/81-86; İbn Kesîr, Tefsîru'l-Kur'âni'l-Azîm, II/58-65; Abdullah Aydemir, İslami Kaynaklara Göre Peygamberler (Ankara: Türkiye Diyanet Vakfı Yayınları (Sabah Gazetesinin Armağanı), 1990), 3741; Muhammed Ahmed Cûd el-Mevlâ, Kasasu'l-Kur'ân (Dimaşk: Daru'l-İlmi'l-Hadis, 1999), 14-17; İslamoğlu, Kur'an ve Tabiat Ayetleri Ișığında Yaratılış ve Evrim, 277.

277 el-Hucurât 49/13.

278 Buhârî, "Ehadisu'l-Enbiyâ", 1; Müslim, "Kasame ve'l-Muhâribîn”, 27; İbn Mâce, "Diyât”, 1; Tirmîzî, "İlim", 14; Ebû Abdirrahmân Ahmed b. Şuayb b. Alî en-Nesâî, Sünenü'n-Nesâî, thk. Muhammed Nâsiruddîn el-Elbânî (Riyad: Mektebetü’l-Maarif, 1998), “Tahrimu'd-Dem”, 1. el-Bakara 2/30.
} 
"kurbanlarınızın etleri ve kanları Allah'a ulaşmaz, Allah'a ulaşan sadece takvanızdır"280 denilmektedir. Âyete göre Kâbil'in Hâbil'i öldürme nedeni kız kardeşle evlilik meselesi değil kurbanın kabulü ile Hâbil'in Kâbil'den daha takvalı olduğunun Allah tarafından belgelenmiş olmasıdır. Kâbil, Allah'a yakınlığı ispatlanan Hâbil'i bu kurban olayından sonra hedef haline getirmiştir. Allah tarafından şeytana tercih edilmesi ve üst bir konuma getirilmesi nedeniyle nasıl ki Hz. Âdem şeytanın düşmanlığının hedefi oldu ise aynı durum Hâbil ve Kâbil için de geçerlidir. Kanaatimizce mesele "hilafet/yönetim" meselesidir. Kurbanı kabul edilen kişinin takvasının kabul edilmesi yönetime ehil görülmesi anlamına gelmekteydi. Hz. İbrahim'in, "neslimden de imamlar kıl" duasına Allah'ın zalimlerin imam olamayacaklarını belirtmesi281 bu işe zalimlerin değil Allah'tan korkanların/muttakilerin ehil olduğunu göstermektedir ki bu da kanımızı desteklemektedir. Dolayısı ile aslında Kâbil'in çekemediği Hâbil'in muttaki olması değil, yönetime seçilmiş olmasıdır.

Âyette belirtilen çocukların Âdem'in öz çocukları mı yoksa neslinden gelen başka birilerinin çocukları mı oldukları da tartışma mevzusudur. ${ }^{282}$ Maturidi, burada ifade edilen kardeşlerin Âdem'in öz evlatları veya neslinden birileri oldukları konusunda kesin bir bilginin bulunmadığını ve bunu bilmenin de önemli olmadığını ifade eder. ${ }^{283}$ Müfessirlerin genel kanaati ise âyette bahsedilen çocukların Hz. Âdem'in öz çocukları olduğu yönündedir ki biz de bu kanaatteyiz. ${ }^{284}$ Şâyet bahsi geçen kardeşler iddia edildiği gibi ilk insanın neslinden gelen iki kardeş değil de İsrailoğullarının soyundan gelen kardeşler olsaydı, katil olan kardeş, ölen birinin toprağa defnedileceğini biliyor olması gerekirdi. ${ }^{285}$

\section{3. İnsanlığın İlk Nasıl Çoğaldığı Sorunu}

İnsanlığın ilk nasıl çoğaldığı öteden beri merak konusu olmuştur. İnsanlığın nasıl çoğaldığı sorusu genelde Maide, 5/27-31. âyetler bağlamında aktarılan "kardeş evliliği” rivâyeti ile cevaplandırılmıştır. Kardeş evliliğinin o dönem geçici olarak meşru kılındığı ve sonradan haram edildiği genel kabul gören bir kanaat olsa da286 böyle bir bilgi Kur'ân ve hadislerde yazmamaktadır. ${ }^{287}$ Kanaatimizce Kur'ân,

\footnotetext{
280 el-Hac $22 / 37$.

281 el-Bakara $2 / 124$.

282 Taberî, Câmiu'l-beyân an te'vîli ayi'l-Kur'ân, 4/242-246; İbn Kesîr, Tefsîru'l-Kur'âni'l-Azîm, II/5865; Maverdî, en-Nuket ve'l-uyûn, 2/27; İbnu'l-Cevzî, Zâdu'l-mesîr fî ilmi't-tefsîr, 373-374; Nesefî, Medâriku't-tenzîl, 282; Râzî, Mefâtîhu'l-ğayb, 11-12/161-163.

283 Mâturîdî, Te'vilâtu'l-Kur'ân, 3/496-498.

284 Taberî, Câmiu'l-beyân an te'vîli ayi'l-Kur'ân, 4/242-246; Zemahșerî, el-Keșşâf an hakâiki gavâmizi't-tenzîl, 1/611; Maverdî, en-Nuket ve'l-uyûn, 2/27-29; İbnu'l-Cevzî, Zâdu'l-mesîr fî ilmi'ttefsîr, 373-374; Râzî, Mefâtîhu'l-ğayb, 11-12/161-163; Beyzâvî, Envâru't-tenzîl ve esrâru'tte'vîl,1/263; Kurtubî, el-Câmi' lî ahkâmi'l-Kur'ân, 3/497-498; İbn Kesîr, Tefsîru'l-Kur'âni'l-Azîm, 2/58-65.

285 Gördük, “İlk İnsan Nesli Nasıl Devam Etti? Ensest İlișki İddiası Üzerine Eleștirel Bir Analiz”, 75.

286 Taberî, Câmiu'l-beyân an te'vîli ayi'l-Kur'ân, 4/242-246; İbn Kesîr, Tefsîru'l-Kur'âni'l-Azîm, 2/5865; Gördük, "lk İnsan Nesli Nasıl Devam Etti? Ensest İliş̧ki İddiası Üzerine Eleştirel Bir Analiz", 67-96; Ateș, "Kur'an'da İnsanların Yaratılışı Meselesi", 367.

287 Okuyan, Kıssalar Ne Söyler Yaratılış ve Hz. Âdem I, 86; Sarmış, Kur'an'a Göre İnsan'ın Yaratılması ve Çoğalması, 66.
} 
insanlığın nasıl çoğaldığı ile değil neden çoğaldığı ile ilgilenmiştir. Buna rağmen birçok müfessir ve araştırmacı bu konuya eğilmiş ve Kur'ân'dan cevap bulmaya çalışmıştır. Şer'i hükümlerin yere, zamana ve kişilere göre farklılık gösterdiği, o dönemin şeriatı hakkında yeterli bilgimizin olmadığı ve zaruretlerin haramları mubah kıldığ ${ }^{288}$ gerekçesi ile kardeş evliliğinin mümkün olabileceği ifade edilmiş 289 ise de kanaatimizce zaruret durumu Allah için değil aciz kullar içindir. Allah dilemiş olsaydı farklı şekillerde nesli çoğaltabilirdi. Dolayısıyla böyle bir gerekçeyi kabul etmek mümkün değildir. İlk insan cinsinin çok fazla fertler şeklinde yaratıldığı ve üremek için, çoğalmak için meşru evlilik ilişkisi gerçekleștirdikleri, ${ }^{290} \mathrm{~Hz}$. Âdem'in neslinden gelenlerin, onun geldiği Homo sapiens kökeninin insanlaşan, sorumluluk sahibi diğer fertleriyle çiftleştiği, böylece ensest ilişki/kardeş evliliği olmadan, insanların başlangıçta bu gruptan türediği de iddia edilmiştir. ${ }^{291}$ Doğrusu "Allah sizleri öncelikle topraktan, sonra nutfeden/meniden halk etti/yarattı. Sonra da sizi çiftler/erkek ve dişi kıldı..."292 âyetinden ve daha birçok âyetten net bir sonuç çıkarmak mümkün değildir. Dolayısı ile söylenen ve söylenecek her söz sadece bir görüşten ibarettir.

“Ey Âdemoğulları"293 ifadesinin geçtiği âyetler, insanların farklı babalardan değil Hz. Âdem'den yaratıldıklarını, nesep olarak ona intisap ettiklerini kanıtlayan delillerden sayılmıştır. ${ }^{294}$ Bizim kanaatimiz insanlığın kardeş evliliği veya insan türünün başta çok fazla bireyler şeklinde yaratılıp kendi aralarında evlenmeleri ile çoğaldığı yönünde değildir. Hz. İsa'nın yaratılması bizim için insanlığın nasıl çoğaldığının delilidir. Babaya ihtiyaç duyulmadan Hz. İsa'nın doğmuş olması insanlığın ilk olarak nasıl çoğaldığı konusunda bizlere ipuçları vermektedir. Kur'ân'da Hz. İsa'nın halinin Hz. Âdem'in haline benzetilmesi ve ardından Hz. Âdem'in topraktan var edilmesinin ifade edilmesi295 insanlığın nasıl çoğaldığına bir gönderme olarak değerlendirilebilir. Kanaatimizce İnsanlık Hz. Âdem ve Havvâ'dan çoğalmıştır. Önce Hz. Âdem'in kız çocukları olmuştur ve onların her biri Hz. Meryem gibi hamile kalıp kız- erkek çocukları doğurmuşlardır. Ardından bu çocuklar/teyze çocukları birbiri ile evlenmişlerdir. Bu çözüm kanaatimizce yaratılış kanununa ve șer'i kanunlara muhalif değildir ve muhtemeldir.

\section{Hz. Âdem Kıssası ve İsrailiyât}

Hz. Âdem'in yaratılışı konusunda rivâyetlerde ve israiliyât dilinde birçok sahih olmayan bilgi verilmektedir. ${ }^{296} \mathrm{~Hz}$. Âdem'in yaratılış serüveni ile ilgili birçok

\footnotetext{
288 el-Bakara 2/173; el-Mâide 5/3; el-En'am 6/145; en-Nahl 16/115; Ahmet Cevdet Paşa, Mecelle-i Ahkâm-ı Adliyye (İstanbul: Matbaa-i Osmaniyye, 1300/1882), 26.

289 Gördük, "İlk İnsan Nesli Nasıl Devam Etti? Ensest İlișki İddiası Üzerine Eleştirel Bir Analiz", 6796.

Özalp, “Kur'an-ı Kerim’de Kozmik Tarih ve Biyolojik Gelișim”, 548.

Taslaman, Bir Müslüman Evrimci Olabilir mi, 96.

Fâtır 35/11.

el-A'râf 7/26, 27, 31, 35, 172; el-İsrâ 17/70; Yâsîn 36/60.

Ateş, "Kur'an'da İnsanların Yaratılışı Meselesi”, 366.

Al-i İmrân 3/59.

Yakıt, Kur'ân'ı Anlamak, 67-68.
} 
konu Kur'ân dışı kaynaklarda detaylı ve Kur'ân'a ters bir şekilde aktarılmaktadır. ${ }^{297}$ Cennette Âdem, Havvâ ve şeytan arasında cereyan eden olaylarla ilgili Müslümanların birçoğu, farkında olmadan Yahudi ve Hıristiyan kültürün öğretisini, bilgisini kabullenmekte, hatta bunun da ötesinde başka din ve kültürlerdeki dinsel ve mitsel inançları benimsemektedir. Çünkü Yahudi-Hıristiyan kültürü, daha çok kendilerinden önceki kültürlerin etkisi altında şekillenmiştir.298

Tevrat'ta anlatıldığı kadarı ile Hz. Âdem, Aden'de bir bahçede 299 topraktan yaratılmış ve ruh burnundan üflenmiştir. ${ }^{300}$ Kadın/Havvâ, erkeğin/Âdem'in kaburga kemiğinden yaratılmıştır. ${ }^{301} \mathrm{~Hz}$. Âdem'e yasaklanan ağaç, iyilik ve kötülüğü bilme ağacıdır. ${ }^{302}$ Âdem ve Havvâ ağaçtan yediklerinde avret yerlerinin farkına vardılar ve incir yapraklarıyla avret yerlerini örttüler. ${ }^{303} \mathrm{~Hz}$. Âdem'i Havvâ, Havvâ'yı da yılan kandırmıştır. Dolayısıyla kadın ve yılan suçludur. ${ }^{304}$ İşlenen bu suçun ardından Âdem yaşadığı bahçeden/cennetten kovulmuştur. ${ }^{305}$

Tevrat'ın ilk günah konusunda suçlu olarak Havvâ'yı göstermesi, Yahudilikteki olumsuz kadın algısının başlıca nedenidir. Hıristiyanlıkta ise Âdem ve Havvâ'nın günahı aslî günaha dönüștürülerek bütün insanlığın günahkâr doğduğu inancı geliştirilmiştir. Buna göre cennetten çıkarılmaya ve ölümlü olmaya neden olmalarından dolayı Âdem ve Havvâ suçludur, günahkârdır. Hz. İsa'nın yeryüzüne gelmesi ve çarmıha gerilmesi de insanlığın bu suçuna/günahına kefaret olmak içindir. Kur'ân'da ise Âdem ve Havvâ'yı kandıranın şeytan olduğu açıkça belirtilmektedir. ${ }^{306}$ Cennetten çıkarılma konusunda ise Kur'ân ve rivâyetler arasında uyuşmazlık söz konusudur. Kur'ân'da erkek ön planda iken rivâyetlerde kadın ön plandadır. ${ }^{307} \mathrm{~Hz}$. Âdem ve cennet hayatı hakkında kaynaklarda gelen ve büyük çoğunluğu israiliyât olan bilgiler buraya alamayacağımız kadar fazladır. ${ }^{308}$

297 Kur'an dışı kaynaklarda Hz. Âdem'in yaratılışı için bk. Erdem, Hazreti Âdem (İlk İnsan), 3-105; Uğur, Tevrat'ın Kur'an'a Arzı, 189-217.

298 Hakkı Şah Yasdıman, "Yılan, Havva, Âdem Arasında Geçen Olaylara İslam ve Yahudiliğin Bakışı", Dokuz Eylül Üniv., İlahiyat Fak. Dergisi 34 (2011), 26-28.

Tekvîn, 2/8-9.

Tekvîn, 2/7.

Tekvîn, 2/21-23.

Tekvîn, 2/16-17.

Tekvîn, 3/7.

Tekvîn, 3/1-14; Tekvîn, 3/1-21.

Tekvîn, 3/22-24.

Asife Ünal, "Yahudi Geleneğinde Kadının Yaratılışı ve Lilit Efsanesi", Çukurova Üniv., İlahiyat Fak. Dergisi 17/2 (2017), 111-112.

Karsl, Kur'an Yorumlarında Kadın, 87.

İlgili bilgiler için bk. Mukâtil bin Süleymân, Tefsiru Mukâtil bin Süleymân, 1/40-43; Taberî, Câmiu'l-beyân an te'vîli âyi'l-Kur'ân, 1/267-269, 310; İbn Kesîr, Tefsîru'l-Kur'âni'l-Azîm, 1/112120; Kurtubî, el-Câmi' lî ahkâmi'l-Kur'ân, 1/262-265; Zemahşerî, el-Keşşâf an hakâiki ğavâmizi'ttenzîl, 130-133; İbn Kesîr, Tefsîru'l-Kur'âni'l-Azîm, 1/112-116; Hâzin, Alâuddîn Alî bin Muhammed bin İbrahîm el-Bağdâdî, Lübâbü't-te'vîl fì meânî́t-tenzîl/Tefsîru'l-Hâzîn, thk. Abdusselâm Muhammed Alî Şâhîn (Beyrut: Dâru'l-Kütübi'l-İlmiyye, 2014), 1/35-40; Aydemir, Tefsirde İsrâiliyyât, 303-341; a. mlf. İslami Kaynaklara Göre Peygamberler, 19-35; Ahmet Cevdet Paşa, Kısas-ı Enbiya (İstanbul: Y.y., 1962), 1/3. 


\section{Sonuç}

İlk insanın yaratılışı, insanlığın çoğalması ve yaratılışa tealluk eden birçok mevzu İslâm ilim tarihi boyunca tartışılmış ve farklı nice fikirlere konu olmuştur. Konuyla ilgili yapılan tartışmaların temelinde ilgili âyetlerin yeterince sarih olmaması, Arap dilinin geniş bir anlam dünyasına sahip olması ve müfessirlerin, araştırmacıların farklı kaynaklardan beslenmeleri yatmaktadır.

Genel kabullerin rivâyetlerle şekillendiği ve rivâyetleri israili haberlerin etkilediği bir gerçek ise de son dönemlerde ileri sürülen görüşlerin de herhangi bir ilmi dayanağı ve tutarlılığı bulunmamaktadır. Kur'ân âyetleri hakkındaki müşkilleri çözmenin yolu Arap dilinin imkân verdiği çerçevenin dışına çıkmamak, Kur'ân bütünlüğünde kalmak ve âyetleri bağlamından koparmamaktır. Biz de makalemizde buna bağlı kalarak yorum yapmaya çalıştık. Ne bilimsel veriler ne de rivâyetler, âyetlerde işlenen yaratılış meselelerini net bir şekilde anlamamıza imkân vermiştir. Bunun içindir ki konuyla ilgili serdedilen tüm görüşlerin kabul edilebilir ve reddedilebilir olduğunu düşünmekteyiz.

Hz. Âdem ve yaratılışla ilgili âyetleri kronolojik tasnife tabi tuttuğumuzda Kur'ân'da yaratılışla ilgili teknik bilgilerin verilmediğini ve kıssaların genelde mesaj verme amaçlı zikredildiğini görürüz. Kur'ân, insanın nasıl yaratıldığı ile değil neden yaratıldığı, insanlığın nasıl çoğaldığı ile değil neden çoğaldığı ile ilgilenir ve bunun için kısmen de olsa tarihi malumatlar verir. Bu malumatlar, insanlığa teknik bilgi vermek için değil özünden uzaklaşan insanlığa yeniden yol göstermek, kurtuluş yoluna iletmek için aktarılır.

Yaratılışla ilgili mevzularda ve farklı fikirlere açık bazı konularda, nasların te'vil edilmesi kimileri tarafından tekfir konusu edilmiştir. Âyetlerin mana ve delaletlerinin sarih olmaması durumunda ileri sürülen farklı fikirlerin tekfir konusu değil sadece tenkit konusu olması gerektiğine inanmaktayız. İlmi araştırmalara açık bırakılan alanlarda düşünce özgürlüğünü tekfirle kısıtlamanın gelişmeye ve üretmeye mâni olduğunu düşünmekteyiz.

Yaratılış mevzusu gaybi bir mesele olması hasebiyle konunun Kur'ân merkezli değerlendirilmesi gerektiğine inanmaktayız. Yaratılış konusunda dün olduğu gibi bugün de son söz söylenmiş değildir. Bizim kanaatlerimiz âyetler hakkındaki düşüncelerimizden ibarettir ve mutlak anlamlar iddiasında asla değildir. Yaptığımız araştırmalar yaratılışla ilgili mevzuların yapılan tüm araştırmalara rağmen hala bakir bir alan olduğunu ve birçok akademik araştırmaya konu olabileceğini göstermiştir. 
59 | Hz. Âdem'in Yaratılışı, İnsanlığın Çoğalması ve Diğer Yaratılış Meselelerinin Kur'ân Açısından Değerlendirilmesi

\section{Kaynakça}

Abdurrahman Hasan Habenneke el-Meydânî. Le yasihhu en yukale el-insânu halifetun anillahi fî arzihi. Beyrut: Mektebetü İhyâi Turâsi'l- İslâmî, 1991.

Agitoğlu, Nurullah. Peygamberimizin (SAS) Dilinden Hz. Âdem. İstanbul: Kitabi Yay., 2015.

Ağırman, Cemal. Kadının Yaratılışı İlgili Rivâyetler Bağlamında Yeni Bir Yaklaşım. İstanbul:

Rağbet Yay., 2001.

Ahmet Cevdet Paşa. Kısas-ı Enbiya. İstanbul: Y.y. 1962.

Ahmet Cevdet Paşa. Mecelle-i Ahkâm-ı Adliyye. İstanbul: Matbaa-i Osmaniyye, 1300/1882.

Aksoy, Süleyman. Kur'ân'ın Embriyolojik Sirları. İstanbul: Kayahan Yay., 2. Basım, 2004.

Alıcı, Mustafa. "İlahi Dinlerde Yaratılış-Evrim Tartışmaları". Akra Kültür Sanat ve Edebiyat Dergisi. 6/14 (2018), 59-89.

Ali Şeriati. Çöle İniş (Hubut-Kevir). Çev. Hicabi Kırlangıç \& Derya Örs. Ankara: Fecir Yay., 3. Basım, 2015.

Arpaguş, Hatice Kelpetin. Osmanlı Halkının Geleneksel İslam Anlayışı ve Kaynakları. İstanbul: Çamlıca Yay., 2001.

Atay, Hüseyin. "Allah'ın Halifesi: İnsan”. Ankara Üniv., İlahiyat Fak. Dergisi. 18 (1970), 75.

Ateș, Ali Osman. Hadis Temelli Kalıp Yargılarda Kadın. İstanbul: Beyan Yay., 2000.

Ateş, Avnullah Enes. "Kur'ân'da İnsanların Yaratılışı Meselesi”. Hitit Üniv., İlahiyat Fak. Dergisi. $15 / 30(2016 / 2), 364$.

Ateș, Süleyman. "Kur'ân-ı Kerim'e Göre Evrim Teorisi". Ankara Üniv. İlahiyat Fakültesi Dergisi, 20 (1975), 138-140.

Ateș, Süleyman. Yüce Kur'ân'ın Çağdaş Tefsiri. 12 Cilt. İstanbul: Yeni Ufuklar Neşriyat, 1988.

Aydemir, Abdullah. Tefsirde İsrailiyyat. İstanbul: Beyan Yay., 2015.

Aydemir, Abdullah. İslami Kaynaklara Göre Peygamberler. Ankara: Türkiye Diyanet Vakfı Yayınları (Sabah Gazetesinin Armağanı), 1990.

Bâr, M. Ali. Kur'ân'ı Kerîm ve Modern Tıbba Göre İnsanın Yaratılışı. Çev. Abdülvehhap Öztürk. Ankara: TDV Yay., ts.

Bayrakdar, Mehmet. İslam'da Evrimci Yaratıllş Teorisi. Ankara: Otto Yay., 2018.

Bayraklı, Bayraktar. Yeni Bir Anlayışın Işı̆̆ııda Kur'ân Tefsîri. 21 Cilt. İstanbul: Bayraklı Yay., 4. Basım, 2013.

Bedir, Ahmet \& Sarsılmaz, Arif. "Hz. Adem'in Boyu”. Harran Üniv., İlahiyat Fak. Dergisi. 4 (1998), 133.

Beyzâvî, Nasiruddîn, Ebû Saîd Abdullâh bin Ömer bin Muhammed eș-Şirâzî. Envâru't-tenzîl ve esrâru't-te'vîl/Tefsîru'l-Beyzâvî. 2 Cilt. Beyrut: Dâru'l-Kütübi'l-İlmiyye, 2002.

Bigiyef, Musa Carullah. Hatun. Çev. Mehmet Görmez. Ankara: Otto Yay., 5. Basım, 2014.

Bilge, Evin. Kutsal Metinlerde Yaratıllş. Dicle Üniv., İlahiyat Fak. Dergisi. 15/1 (2013), 128-158.

Bilgin, Abdülcelil. Kur'ân'ı Tanımak. Ankara: Araştırma Yay., 2018.

Birinci, Züleyha. "Nefs-i vâhide' İfadesinden Hareketle Kadının Yaratılışı Hakkında Bir Değerlendirme". Marmara Üniv. Illâhiyat Fak. Dergisi. 47 (2014), 159.

Bolay, Süleyman Hayri. “Âdem”. DİA. Ankara: TDV Yay., 1988.

Buhârî, Ebû Abdullâh Muhammed bin İsmâîl el-Cu'fî. Sahîhu'l-Buhârî. Thk. Muhammed Nizâr Temîm-Heysem Nizâr Temîm. Beyrut: Dâru'l-Erkâm, ts.

Cerrahoğlu, İsmail. Kur'ân'da İnsanın Yaratılış Sahnesinin Düşündürdükleri. Ankara Üniv. İlahiyat Fak. Dergisi, 20 (1975), 87.

Cevherî, İsmâîl bin Hammâd. Mu'cem es-sıhâh. Thk. Halîl Me'mun Şeyhâ. Beyrût: Dâru'l-Ma'rife, 3. Basım, 2008.

Cihangir, Sonia. Kadına Dair Hürafeler ve Gerçekler. İstanbul: Ozan Yay., 2016. 
Çelik, Hüseyin. “Kur'ân'a Göre Hz. Âdem'in Yaratılıșı". İstanbul Üniv., İlahiyat Fak. Dergisi. 2/2 (2011), 62-65.

Dartma, Bahattin. "Kur'ân Bağlamında İlk İnsan ve Nübüvvet-Fıtrat İlişkisi”. Dinbilimleri Akademik Araştırma Dergisi. 1 (2006/6), 10-11.

Dartma, Bahattin. "Hz. Âdem'in Dışlandığı Cennetin Dünyası Meselesi”. Dinbilimleri Akademik Araștırma Dergisi. 2 (2009/9), 11-21.

Demir, Şehmus. Mitoloji, Kur'ân Kıssaları ve Tarihi Gerçeklik. İstanbul: Beyan Yay., 2. Basım, 2015.

Demirci, Muhsin. Kur'ân'ın Ana Konuları. İstanbul: İFAV Yay., 4. Basım, 2008.

Demirci, Muhsin. Kur'ân Tefsirinde Farkll Yorumlar. 3 Cilt. İstanbul: İFAV Yay., 2017.

Duman, Cengiz. Kur'ân Kıssalarının Tarihselliği. İstanbul: Ekin Yay., 2015.

Düzgün, Şaban Ali. Sarp Yokuşun Eteğinde İnsan. Ankara: Otto Yay., 2016.

Ebû Hâtim er-Râzî, Ahmet bin Hamdân. Kitâbu'z-zînê. Thk. Saîd el-Ğânimî. 2 Cilt. Beyrut: Menşûrâti'l-Cemel, 2015.

Ebu Hilâl el-Askerî, Hasen bin Abdullâh. el-Vücûh ve'n-nezâir fi'l-Kur'âni'l-Kerîm. Thk. Ahmed es-Seyyid. Beyrut: Dâru'l-Kütübi'l-İlmiyye, 2010.

Elik, Hasan\&Coşkun, Muhammed. Tevhit Mesajı Özlü Kur'ân Tefsiri. İstanbul: Fikir Yay., 2013.

Erdem Mustafa. Hazreti Âdem (Illk Insan). Ankara: TDV Yay., 9. Basım, 2017.

Esen, Muammer. “İnsanın Halifeliği Meselesi”. Ankara Üniv. İlahiyat Fak. Dergisi. 45 (2004), 1537.

Ezherî, Ebû Mansûr Muhammed b. Ahmed. Mu'cemu tehzîbi'l-luğâa. Thk. Riyâz Zekî Kâsım. 4 Cilt. Beyrut: Dâru'l- ma'rife, 2001.

Ferâhîdî, Ebû Abdurrahmân Halîl b. Ahmed. Kitâbu'l-ayn. Thk. Dr. Davud Sellum v.dğr. Beyrut: Mektebetü Lübnân, 2004.

Firuzâbâdî, Mecdüddîn Muhammed bin Ya'kub. el-Kâmusu'l- muhit. Thk. Halil Me'mun Şeyhâ. Beyrut: Dâru'l-Ma'rife, 5. Basım, 2011.

Gördük, Yunus Emre. “ilk İnsan Nesli Nasıl Devam Etti? Ensest İlişki İddiası Üzerine Eleştirel Bir Analiz". Usul İslam Araştırmaları. 29 (2018), 73.

Gördük, Yunus Emre. "Klasik ve Modern Kaynaklarda İlk Cinayet Kıssası (Maide 5/27-31): Tefsir Metodolojisi Açısından Mukayeseli Bir İnceleme". Amasya İlahiyat Dergisi, 15 (2020): 105-142.

Görener, İbrahim. “Âdemin Cennetten Yeryüzüne İnişi”. Bilimname Dergisi. 18 (2010/1), 61.

Deniz, Gürbüz. “Kur'ân'a Göre Hz. Âdem(a.s.)'ın Serüveni”. Journal of Islamic Research. 22/2 (2011), 93.

Halefullah, Muhammed Ahmed. el-Fennü'l- Kasasi -Kur'ân'da Anlatım Sanatı. Çev. Şaban Karataș. Ankara: Ankara Okulu Yayınları, 2012.

Hâlidî, Salâh Abdûlfettâh. Kur'ân Öyküleri. Çev: Ahmet Sarıkaya. Konya: Kitap Dünyası, 2002.

Hâzin, Alâuddîn Alî bin Muhammed bin İbrahîm el-Bağdâdî. Lübâbü't-te'vîl fí meânîtttenzîl/Tefsîru'l-Hâzîn. Thk. Abdusselâm Muhammed Alî Şâhîn. 4 Cilt. Beyrut: Dâru'lKütübi'l-İlmiyye, 3. Basım, 2014.

İbn Arabî, Muhyiddin Ebû Abdillah Muhammed b. Ali. Fusûsu'l-Hikem. Çev. M. Nuri Gençosman. İstanbul: Kırkambar Yay., 2003.

İbnu'l-Cevzî, Ebû'l-Ferâc Cemalüddîn Abdurrahmân bin Alî bin Muhammed. Zâdu'l-mesîr fî ilmi't-tefsîr. Beyrut: Dâru İbn Hazm, 2015.

İbnu'l-Cevzî, Ebû'l-Ferâc Cemalüddîn Abdurrahmân bin Alî bin Muhammed. Nüzhetü'la'yüni'n-nevâzır fi ilmi'l-vücûh ve'n-nezâir. Thk. Muhammed Osmân. Kâhire: Mektebetu's-Sekâfeti'd-Diniyye, 2. Basım, 2014. 
61 | Hz. Âdem'in Yaratılıșı, İnsanlığın Çoğalması ve Diğer Yaratılış Meselelerinin Kur'ân Açısından Değerlendirilmesi

İbn Dureyd, Ebû Bekr Muhammmed b. Hasan el-Ezdî. Cemheratu'l-luğâ. Thk. İbrahîm Şemsuddîn. Beyrut: Dâru'l-Kütübi'l-İlmiyye, 2005.

İbn Fâris, Ebu'l Huseyn Ahmed bin Zekeriyyâ. Mekâyîsu'l-luğâ. Thk. Enes Muhammed eş-Şâmî. Kâhire: Dâru'l-Hadîs, 2008.

İbn Fâris el-Luğavî, Ebû'l-Huseyn Ahmed er-Razî. es-Sâhibiyyu fí fikhi'l-lûğâti'l-Arabiyyeti ve mesâilihê ve süneni'l-Arab fî kelâmihê. Thk. Dr. Ömer Farûk Tabbâ'. Beyrut: Dâru Mektebetü'l-Meârif, 3. Basım, 2013.

İbn Kayyim el-Cevziyye, Ebû Abdullâh Şemsuddîn Muhammed bin Ebû Bekr. Hâdi'l-ervah ilâ bilâdi'l-efrâh. Thk. Zâid bin Ahmed en-Neşînî. Mekke: Dâru'l-Âlemi'l-Fevâid, 1428.

İbn Kesîr, İmâduddîn Ebû'l-Fidâ İsmail bin Ömer el-Kureșî. Tefsîru'l-Kur'âni'l-Azîm. 4 Cilt. Kahire: Dâru'l-Hadîs, 7. Basım, 1993.

İbn Kuteybe, Ebû Muhammed Abdullâh bin Müslim ed-Dineverî. Tefsîru garîbu'l-Kur'ân. thk. Seyyid Ahmed Sakr. Beyrut: Mektebetü'l-Alemiyye, 2007.

İbn Mâce, Ebû Abdullâh Muhammed bin Yezîd el-Kazvînî. Sünenü İbn Mâce. Thk. Halîl Me'mûn Şihâ. 2 Cilt. Beyrut: Dâru'l-Ma'rife, 1998.

İbn Manzûr, Ebu'l-Fazl Cemâlüddîn Muhammed bin Mukerrem el-Ifrikî el-Mısrî. Lisânu'l-Arab. Thk. Yusuf Bekai v.dğr. 2 Cilt. Beyrut: Müesseseti'l-A'lem li'l-Matbuât, 2005.

İbn Sîde, Ebû Hasen Alî bin İsmâîl el-Mursî. el-Muhkem ve'l-muhit el-a'zam. Thk. Abdulfettâh es-Seyyid Selim- Huseyn Birkân. 3 Cilt. Kahire: Ma'hed Mahtutati'l-Arabiyye, 2011.

İslamoğlu, Mustafa. Kur'ân ve Tabiat Âyetleri Işı̆̆ında Yaratılış ve Evrim. İstanbul: Düşün Yay., 2015.

Kahraman, Ferruh. “Bir Tefsîr-Kelâm Problemi: Hz. Âdem'in Yasak Ağaca Yaklaşması”. Sakarya Üniv., Ilahiyat Fak. Dergisi. 15/27 (2013/1).

Kahraman, Ferruh. "Hz. Âdem'e Öğretilen İsimler: Kültür Olgusunun Sembolik Söylemi". Edebali İslamiyat Dergisi. 4/2 (2020), 15-40.

Kara, Ömer. Tefsir Tedkikleri I. İstanbul: İFAV Yay., 2017.

Karasakal, Şaban. "Kur'ân'da Ruh Kavramı". The Journal of Academic Social Science Studies. 28/2 (2014), 288-289.

Karataş, Şaban. Muhammed Ahmed Halefullah Eserleri ve Kur'ân Tefsiri ile Illgili Görüşleri. Ankara: Ankara Okulu Yayınları, 2011.

Karauğuz, Güngör. Âdem'in Çocukları Çiviyazılı Kaynaklar, Tevrat, İnciller ve Kur'ân'a Göre. Konya: Çizgi Yay., 3. Basım, 2017.

Karslı, İbrahim H. Kur'ân Yorumlarında Kadın. İstanbul: Rağbet Yay., 2003.

Kâsımî, Muhammed Cemaluddîn. Mehâsinu't-te'vîl/Tefsîru'l-Kasimî. Thk. Ahmed bin Alî. Hamdî Subh. 9 Cilt. Kahire: Dâru'l-Hadîs, 2003.

Kavşut, M. Sait. "Kur'ân'da İnsanın Yaratılıș Așamaları Te'vilat Ekseninde Bir Değerlendirme". Şarkiyyat Ilmi Araştırmalar Dergisi. 7 (2012), 289-300.

Keskin, Hasan. "Kur'ân'da Meleklerin Hz. Âdem'e Secdesinin Yorumu”. Cumhuriyet Üniv., İlahiyat Fak. Dergisi. 6/2 (2002), 107.

Kılavuz, Ulvi Murat. "Arâisü'l-Kur'ân'da Yaratılıș Kıssası". Ulusal Vânî Mehmed Efendi Sempozyumu 7-8 Kasım 2009 (Bursa, 2011), 171.

Kınıkoğlu, Nihat. "Varoluş, Evrim, İnsan ve İslam”. İslami Araştırmalar Dergisi. 7/1 (1993-94), 76.

Kocabaş, Şakir. Kur'ân'da Yaratıllş Uzayların ve Maddenin Yaratıllşsı. İstanbul: Kure Yay., 2. Basım, 2017. 
Kurtubî, Ebû Abdullah Muhammed bin Ahmed el-Ensârî. el-Câmi' lî ahkâmi'l-Kur'ân. Thk. Muhammed İbrahim el-Hafnevî-Mahmûd Hâmîd Osmân. 12 Cilt. Kahire: Dâru'l-Hadîs, 2002.

Mâturîdî, Ebû Mansûr Muhammed bin Muhammed bin Mahmûd. Tevilâtü Ehli'sSünne/Te'vilâtu'l-Kur'ân. Thk. Dr. Mecdi Basillum. 10. Cilt. Beyrut: Dâru'l-Kütübi'lİlmiyye, 2005.

Maverdî, Ebû'l-Hasen Alî bin Muhammed. en-Nuket ve'l-uyûn. Thk. Seyyid Abdulmaksud bin Abdurrahîm. 6 Cilt. Beyrut: Dâru'l-Kütübi'l-İlmiyye, ts.

Merdin, Saadettin. İslamın Pavlusları II. Ankara: Araştırma Yay., 3. Basım, 2016.

Mevdüdi Ebu'l-Ala. Tefhimu'l-Kur'ân. Çev. Muhammed Han Kayani v.dğr. İstanbul: İnsan Yay., 2. Basım, 1996.

Muhammed Ahmed Cûd el-Mevlâ. Kasasu'l-Kur'ân. Dimaşk: Daru'l-İlmi'l-Hadis, 1999.

Muhammed Fuâd Abdulbâkî. el-Mu'cemu'l-müfehres li elfâzı'l-Kur'âni'l-Kerîm. Kâhire: Dâru'lHadîs, 2007.

Muhammed İkbal. İslamda Dini Tefekkürün Yeniden Teșekkülü. Çev. Sofi Huri. İstanbul: Kırkambar Yay., 1999.

Mukâtil bin Süleymân bin Beşîr. el-Eşbâh ve’n-nezâir fi'l-Kur'âni'l-Kerîm. Thk. Abdullâh Șehhâte. Kâhire: Dâru Ğarib, 2001.

Mukâtil bin Süleymân bin Beşîr. Tefsiru Mukâtil bin Süleymân. Thk. Ahmed Ferid. 3 Cilt. Beyrut: Dâru'l-Kütübi'l-İlmiyye, 2003.

Müslim bin Haccâc, Ebû Huseyn el-Kuşeyrî. Sahîhu Müslim. Thk. Ahmed Zehve- Ahmed İnaye. Beyrut: Dâru'l-Kitâbi'l-Arabî, 2004.

Nehhâs, Ebû Ca'fer Ahmed bin Muhammed bin İsmail. Meâni'l-Kur'ân. Thk. Yahya Murad. 2 Cilt. Kahire: Dâru'l-hâdis, 2004.

Nesâî, Ebû Abdirrahmân Ahmed b. Şuayb b. Alî. Sünenü'n-Nesâî. Thk. Muhammed Nâsiruddîn el-Elbânî. Riyad: Mektebetü'l-Maarif, 1998.

Nesefî, Abdullâh bin Ahmed bin Mahmûd. Medâriku't-tenzîl ve hakâiku't-te'vîl/Tefsîru'n-Nesefí. Beyrut: Dâru'l-Ma'rife, 2000.

Okçu, Abdulmecit. "Kur'ân ve Evrim Açısından Canlıların Oluşumu". EKEV Akademi Dergisi. 17/56 (2013), 174.

Okumuş, Namık Kemal. Eşref'ten Esfel'e Insanın Serüveni. Ankara: Araştırma Yay., 2015.

Okuyan, Mehmet. Kıssalar Ne Söyler Yaratılış ve Hz. Âdem I. İstanbul: Düşün Yay., 2017.

Okuyan, Mehmet. Kıssalar Ne Söyler Hz. Nuh II. İstanbul: Düşün Yay., 2018.

Özalp, Hasan. “Kur'ân-ı Kerim'de Kozmik Tarih ve Biyolojik Gelişim”. Turkish Studies, International Periodical For The Languages, Literature and History of Turkish or Turkic. 10/1 (2015), 548.

Özdeş, Talip. Kur'ân ve Cinsiyet Ayırımcılı̆̆ı. Ankara: Fecr Yay., 2005.

Öztürk, Mustafa. Kur'ân ve Yaratılış. İstanbul: Kuramer Yay., 2015.

Öztürk, Mustafa. Kıssaların Dili. Ankara: Ankara Okulu Yay., 3. Basım, 2012.

Ragıb el-İsfehânî, Ebu'l-Kâsım Huseyn bin Muhammed. el-Müfredât fì garîbi'l-Kur'ân. Thk. Muhammed Halil Ayteni. Beyrut: Dâru'l-Ma'rife, 3. Basım, 2001.

Rasıkhî Füruzan. “Kur'ân'ın ve Kutsal Kitabın Kadına Bakış Açılarının Karşılaştırılması (Yaratılış Hikâyesine Göre)”. Misbah Dergisi. 1/3-4 (2013), 157.

Râzî, Fahruddîn Muhammed bin Ömer bin Hasen bin Huseyn bin Alî et-Teymî. Mefâtîhu'lğayb/Tefsîru'l-kebîr. Thk. İbrahîm Şemsuddîn, Ahmed Şemsuddîn. 23 Cilt. Beyrut: Dâru'l-Kütübi'l-İlmiyye, 4. Basım, 2013. 
63 | Hz. Âdem'in Yaratılıșı, İnsanlığın Çoğalması ve Diğer Yaratılış Meselelerinin Kur’ân Açısından Değerlendirilmesi

Reşîd Rizâ, Muhammed. Tefsîru'l-Kur'âni'l-Hakîm. Thk. İbrahim Şemsuddîn. 12 Cilt. Beyrut: Dâru'l-Kütübi'l-İlmiyye, 3. Basım, 2011.

Said Nursi. İşaratü'l-I'caz. Çev. Abdulmecid Nursi. İstanbul: Sözler Yayınevi, 2004.

Sarmış, İbrahim. Kur'ân'a Göre İnsan'ın Yaratılması ve Çoğalması. İstanbul: Düşün Yay., 2016.

Şimşek, M. Sait. Kur'ân Kıssalarına Giriş. Konya: Kitap Dünyası Yay., 3. Basım, 2013.

Şimşek, M. Sait. Yaratılış Olayı. İstanbul. Beyan Yay., 1998.

Şimşek, M. Sait. Hayat Kaynağı Kur'ân Tefsiri. 5 Cilt. İstanbul: Beyan Yay., 2012.

Tabbara, Abdulfettah. Kur'ân'da Peygamberler ve Peygamberimiz. Çev. Ali Rıza Temel\&Yahya Alkın. İstanbul: Miili Gazete, 1998.

Taberî, Ebû Ca'fer Muhammed bin Cerîr. Câmiu'l-beyân an te'vîli âyi'l-Kur'ân. 15 Cilt. Beyrut: Dâru İbn Hazm, 2013.

Tabresî, Ebû Alî el-Fazl bin Hasen bin el-Fazl. Mecmau'l-beyân fî tefsîri'l-Kur'ân. Thk. İbrahim Şemsuddîn. 10 Cilt. Beyrut: Dâru'l-Kütübi'l-İlmiyye, 1997.

Tâhir bin Âşûr, Muhammed. Tefsîru't-Tahrîr ve't-Tenvîr. 12 Cilt. Tûnus: Dâru Suhnûn li'n-Neşr ve't-Tevzi', ts.

Taslaman, Caner. Bir Müslüman Evrimci Olabilir mi. İstanbul: Destek Yay., 2017.

Taslaman, Caner. Evrim Teorisi Felsefe ve Tanrı. İstanbul: İstanbul Yay., 20. Basım, 2016.

Tirmîzî, Ebû İsâ Muhammed bin İsâ bin Sevre. Sünenü't-Tirmîzî. Beyrut: Dâru'l-Ma'rife, 2002.

Tuksal, Hidâyet Şefkatli. Kadın Karşıtı Söylemin İslâm Geleneğindeki İzdüşümleri. Ankara: Otto Yay., 4. Basım, 2012.

Tûsî, Ebû Ca'fer Muhammed bin el-Hasen. et-Tibyân fi tefsîri'l-Kur'ân. Thk. Ahmed Habîb Kasîr el-Âmîlî. 10. Cilt. Beyrut: Müessesetü'l-A'lemî li'l-Matbuât, 2013.

Uğur, Hakan. Tevrat'ın Kur'ân'a Arzı. Bursa: Emin Yay., 2011.

Ünal, Asife. "Yahudi Geleneğinde Kadının Yaratılışı ve Lilit Efsanesi". Çukurova Üniv., İlahiyat Fak. Dergisi. 17/2 (2017), 111-112.

Yakıt, İsmail. Kur'ân’ı Anlamak. İstanbul: Ötüken Yay., 2005.

Yasdıman, Hakkı Şah. "Yılan, Havva, Âdem Arasında Geçen Olaylara İslam ve Yahudiliğin Bakışı". Dokuz Eylül Üniv., İlahiyat Fak. Dergisi. 34 (2011), 26-28.

Yeniçeri, Celal. Uzay Âyetleri Tefsiri. İstanbul: Erkam Yay., 1995.

Yuval Noah Harari. Hayvanlardan Tanrılara Sapıens İnsan Türünün Kısa Bir Tarihi. Çev. Ertuğrul Genç. İstanbul: Kolektif Yay., 7. Basım, 2015.

Zemahșerî, Ebû'l-Kâsım Cârullah Mahmûd bin Ömer bin Muhammed. Esâsu'l-belâğa. Dimeșk: Dâru'n-Nefâis, 2009.

Zemahşerî, Ebû'l-Kâsım Cârullah Mahmûd bin Ömer bin Muhammed. el-Keşşâf an hakâiki ğavâmizi't-tenzîl ve uyûnu'l-ekâvîl fî vucûhu't-te'vîl. Thk. Muhammed Abdusselâm Şâhîn. 4 Cilt. Beyrut: Dâru'l-Kütübi'l-İlmiyye, 1995. 